SUBSURFACE STORAGE OF FRESHWATER IN SOUTH FLORIDA: A PROSPECTUS

By Michael L. Merritt, Frederick W. Meyer, Wayne H. Sonntag, and Daniel J. Fitzpatrick

U.S. GEOLOGICAL SURVEY

Water-Resources Investigations Report 83-4214

Prepared in cooperation with the

U.S. ARMY CORPS OF ENGINEERS

Ta1lahassee, Florida 
UNITED STATES DEPARTMENT OF THE INTERIOR

WILLIAM P. CLARK, Secretary

GEOLOGICAL SURVEY

Dallas L. Peck, Director

For additional information write to:

District Chief U.S. Geological Survey Suite 3015 227 North Bronough Street Tallahassee, Florida 32301
Copies of this report can be purchased from:

Open-File Services Section Western Distribution Branch U.S. Geological Survey Box 25425, Federal Center Denver, Colorado 80225 (Telephone: (303) 234-5888) 
Abstract--------------

Introduction----

Purpose and scope-- 4

Previous and other current studies-- 4

Acknowledgments-------- 6

Part I - Freshwater-supply deficiencies-_- 6

Martin County----

Palm Beach County---- 10

Broward County-- 12

Dade County------------

Monroe County--

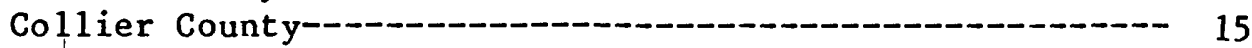

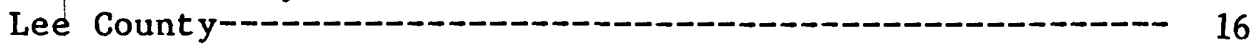

Charlotte County----

Hendry County--

Glades County-----

Part II - Availability of surplus freshwater-------------- 19

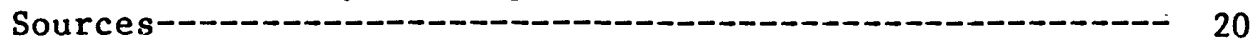

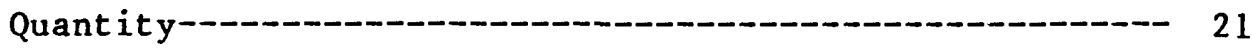

Quality-------------

Conveyance to location of use--

Part III - Regional appraisal of geologic suitability

for injection-- 28

Avon Park and Ocala Limestones-- 29

Suwannee Limestone-------

Tampa Limestone---

Hawthorn Formation (lower part)- 42

Hawthorn Formation (upper part) 44

Tamiami Formation--

Part IV - Installation and operation of injection system----- 45

Selection of injection sites--

Preliminary data collection and analysis-------------- 45

Wel1 design and construction-- 1

Injection and withdrawal tests-

We11-field development--

Part V - Factors affecting freshwater recoverability-------- 56

Relation to hydrogeologic parameters---

Relation to design and management parameters--------- 58

Part VI - Further investigative needs-- 59

Summary---

Selected references- 64 
Figure 1. Map showing study area and locations of freshwater injection tests-

2. Map showing major features of the water-management system of south Florida-

3. Map showing sites in south Florida where controlled or uncontrolled surface discharge from the watermanagement system is measured--

4. Idealized hydrogeologic section $A-A^{\prime}$ across south Florida showing possible injection zones--

5. Contours showing the top of upper and middle Eocene rocks (Zone I) in south Florida-_.

6. Sketch showing construction of a typical freshwater injection and recovery well in south Florida-----

\section{TABLES}

Table 1. Freshwater use in south Florida during 1977-

2. Mean discharge during 1970-80 water years, and percent of time discharge magnitude was equaled or exceeded at selected sites ( $f i g .3$ ) for indicated periods of months during 1970-81 water years--.--

3. Generalized stratigraphic units and associated hydrogeologic properties in south Florida-------

4. Results of U.S. Geological Survey injection and recovery tests at site 5 in Orange County, 1969-70--

5. Results of City of St. Petersburg injection, storage, and recovery tests at site 1 in Pinellas County, 1973-74-

6. Results of Florida Department of Natural Resources and Florida Department of Environmental Regulation injection, storage, and recovery tests at site 2 in northeast Palm Beach County, 1975-76-

7. Results of U.S. Geological Survey injection, storage, and recovery tests at site 3 in Dade County, 1975-80

8. Results of U.S. Geological Survey injection, storage, and recovery tests at site 4 in Lee County, 1980-82 


\title{
SUBSURFACE STORAGE OF FRESHWATER IN SOUTH FLORIDA: A PROSPECTUS
}

by Michael L. Merritt, Frederick W. Meyer, Wayne H. Sonntag and Daniel J. Fitzpatrick

\begin{abstract}
Public agencies in south Florida have investigated various means for increasing the storage capacity of the water-management system, such as injection of freshwater into brackish aquifers, because of concern that increased demand during future dry seasons might cause water-supply deficiencies. In most parts of south Florida, freshwater deficiency usually becomes manifest as the encroachment of saline water into well fields. In some localities, it means the complete absence of natural ground-water supply.

Surplus freshwater for injection might be available during the wet season from the same surface and subsurface sources that may become deficient in their capacity to supply local needs during the dry season. Quantification of the amount of surplus freshwater available from a given source requires site-specific analyses. The chemical composition of the surplus water and its proximity to the location of use or to an intervening conveyance system determine whether it is a suitable source for injection.
\end{abstract}

Most of south Florida is underlain by saline, permeable artesian zones which have potential for freshwater storage. These are in the Avon Park, Ocala, Suwannee, and Tampa Limestones, and in the Hawthorn Formation. Experimental freshwater injection tests have been performed with varying degrees of success at five locations, in which surplus water has been stored in either the Avon Park, the Suwannee, or the Hawthorn.

A determination of the feasiblity of cyclic freshwater injection at a selected site begins with an assessment of the suitabi1ity of local geologic conditions, guided by a knowledge of regional hydrogeology. Feasibility can only be established by actual injec$t$ ion and recovery tests, because some aquifer characteristics affecting freshwater movement during inflow and outflow (degrees of flow uniformity, anisotropy, and hydrodynamic dispersion) are not measurable with standard techniques. Injection and withdrawal tests determine recovery efficiency, the measure of the success of the operation. This is defined for each cycle as the percentage of injected freshwater that can be recovered before the dissolved solids exceed Secondary National Drinking Water Standards. As recovery efficiency improves during the first few cycles, several similar injection and withdrawal tests should be performed in succession. Computer simulations have been made to elucidate the relation of recovery efficiency with various hydrogeologic conditions and with design and management factors.

The hydraulic characteristics of the injection zone determine the maximum practical injection capacity of a single well. This, together with the recovery efficiency obtained from a test injection we 11 and local water-supply requirements, determines the number of wells required and the cost-effectiveness of the proposed system relative to other water-supply or conservation alternatives. 


\section{INTRODUCTION}

Continued rapid urbanization of south Florida places an increasing burden upon the system of public water supply, and there is concern whether future needs of the public will be satisfied. An important part of the water-management system is its storage areas, consisting of reservoirs such as Lake Okeechobee and the water-conservation areas, from which a network of canals delivers needed water to coastal urban areas during dry periods and discharges excess storage to the ocean during wet periods (Leach and others, 1972; Klein and others, 1974). The capacity of these surface storage areas may become inadequate, and their enlargement is limited by the flat topography, the growing scarcity of available land, and the desire to preserve nearby wilderness and wetland areas. The topography and climate are responsible for substantial losses of water from surface reservoirs by evapotranspiration and seepage.

Recent public interest has focused upon a novel method of increasing storage capacity, the use of confined aquifers with suitable hydraulic properties and containing water considered nonpotable because of its high chloride (and other dissolved solids) content. Freshwater would be injected into a saline aquifer through wells and then be withdrawn later when needed. This concept is particularly relevant to south Florida, where underlying artesian aquifers are nearly everywhere saline, where the surficial aquifers follow a seasonal cycle of surplus and deficit in some localities where they are a principal source of public supply, and where demand is substantially greater during the dry part of the cycle. It differs from the concept of artificial recharge to freshwater aquifers (Cohen and Durfor, 1967; Vecchioli and others, 1975), where the objective is usually to raise water levels to increase the availability of potable water and to forestall the intrusion of saline water, in that only injected water can be recovered and used.

The source of freshwater for injection into the artesian aquifers would be the surplus available within the surface-water management system during the annual wet season or the surficial aquifers, such as the Biscayne, which are replenished by rainfall during the wet season. The term "cyclic injection" implies that injection and recovery might be done annually, with injection during the wet season followed by a short storage period and subsequent withdrawal of the injected freshwater as needed during the dry season.

A measure of the success of a cycle of injection, storage, and recovery is the recovery efficiency. Usually expressed as a percentage of the volume injected, this is defined as the volume of water recovered before withdrawn water fails to meet some established chemical standard. In all operational tests to date (1983) in south Florida, this has been taken to be when withdrawn water exceeds the maximum chloride concentration $(250 \mathrm{mg} / \mathrm{L})$ deemed acceptable for use for human consumption (potable) according to the standards of the U.S. Environmental Protection Agency (1977). other chemical criteria might be established, however, as compatible with the particular objectives of some injection program. 
Some advantages inherent in the subsurface storage concept are that subsurface space is available at no cost, and that its location can be chosen for maximum convenience (directly underneath a water-treatment plant or near a major conduit), subject to favorable hydrogeologic conditions. Deep subsurface reservoirs do not lose water by evapotranspiration. The particular significance of the subsurface storage alternative for south Florida is that it takes advantage of the seasonal, or cyclic, nature of local water availablility. Theoretical studies, augmented by tentative evidence from operational tests, indicate that recovery efficiency improves markedly in the first few cycles, provided that only potable water is recovered in each cycle.

Aspects of the scheme which might be relatively disadvantageous include the cost of geologic testing, construction of wells into deeper artesian zones, and the operation of a system of cyclic injection wells. In addition, some freshwater injected into underground reservoirs is contaminated by dispersive mixing with the native saline water, and its recoverability can be reduced by lateral migration, buoyancy stratification, or permeability changes. Unfavorable hydrogeologic and chemical characteristics of aquifers can enhance these deleterious processes and reduce the recoverability of potable water, as can the inappropriate design of a system of wells or an inappropriate operational regime.

An evaluation of the feasibility of the cyclic injection concept requires an understanding of all of these factors. The U.S. Army Corps of Engineers has been charged with the responsibility of assessing the feasibility of the alternative for south Florida. The U.S. Geological Survey, in turn, has provided technical support in the form of a study of the multiple and diverse facets of the concept: (1) potable water deficiencies that occur in the area; (2) water availability; (3) location of suitable underground formations; (4) geologic testing and site evaluation; (5) system design and construction; (6) operational problems; and (7) the effect of hydrogeologic, design, and management parameters upon recoverability.

The discussion of water availability is based partly upon a statistical analysis of discharge at selected coastal and inland sites documented separately in a more detailed report ( $W$. H. Sontag, written commun., 1981). The discussion of recoverability is based upon a theoretical analysis using digital models of groundwater solute transport, which is documented separately and in greater detail (Merritt, 1983). These two supporting reports were prepared as a part of this study.

Concurrent studies providing additional information were the evaluation of the southeast Tertiary limestone aquifer system (Johnston, 1978; and F. W. Meyer, written commun., 1981) and the evaluation of data acquired during operational cyclic injection tests conducted by the U.S. Geological Survey at Hialeah in Dade County (F. W. Meyer, oral commun., 1980) and near Fort Myers in Lee County (D. J. Fitzpatrick, written commun., 1982). 


\section{Purpose and Scope}

This prospectus report presents no original investigative results, but relies upon those of studies documented separately for the preparation of synopses of diverse topics related to cyclic injection and recovery of freshwater in that part of south Florida (fig. 1) underlain by saline artesian aquifers. The report is intended to aid the U.S. Army Corps of Engineers and other water managers by addressing fundamental issues such as: (1) where and why additional water may be needed; (2) from what sources surplus freshwater may be obtained; (3) where saline aquifers may be found; (4) how to inject and recover freshwater; (5) what conditions favor operational success; (6) how to assess feasibility of the scheme at selected sites; and (7) what still needs to be learned about the practice.

The first subject is addressed with a summary of freshwatersupply problems in south Florida based upon U.S. Geological Survey reports of areal studies in the region. The second issue receives a discussion partly based upon quantities of water used (Leach and Healy, 1979) and quantities of water discharged at coastal and inland sites (W. H. Sonntag, written commun., 1981). The third issue is addressed with a section describing the hydrogeology of south Florida artesian zones which is a synopsis of preliminary conclusions of another investigation (F. W. Meyer, written commun., 1981). The fourth and sixth subjects are addressed with a consideration of factors involved in the construction of cyclic injection wells in south Florida and a discussion of operational testing and monitoring. This is a synopsis of practical knowledge of the subject within the U.S. Geological Survey. The fifth subject is discussed in a section summarizing the results of a study utilizing mathematical models (Merritt, 1982; 1983). The fifth and final issue motivates a section discussing gaps in existing knowledge about the nature of flow in the limestone aquifers of south Florida and cites the need for additional operational tests.

\section{Previous and Other Current Studies}

A study of the cyclic injection concept by Kimbler and others (1975) was concerned with the development of theoretical equations relating the various processes controlling and limiting the recoverability of freshwater in a vertically uniform aquifer. The construction of a physical model permitted partial verification. The results were implemented by Khanal (1980) in a theoretical investigation of cyclic injection feasibility in the Upper East Coast Planning Area for the South Florida Water Management District (SFWMD). SFWMD has considered the cyclic injection concept in planning efforts (South Florida Water Management District, 1978). 


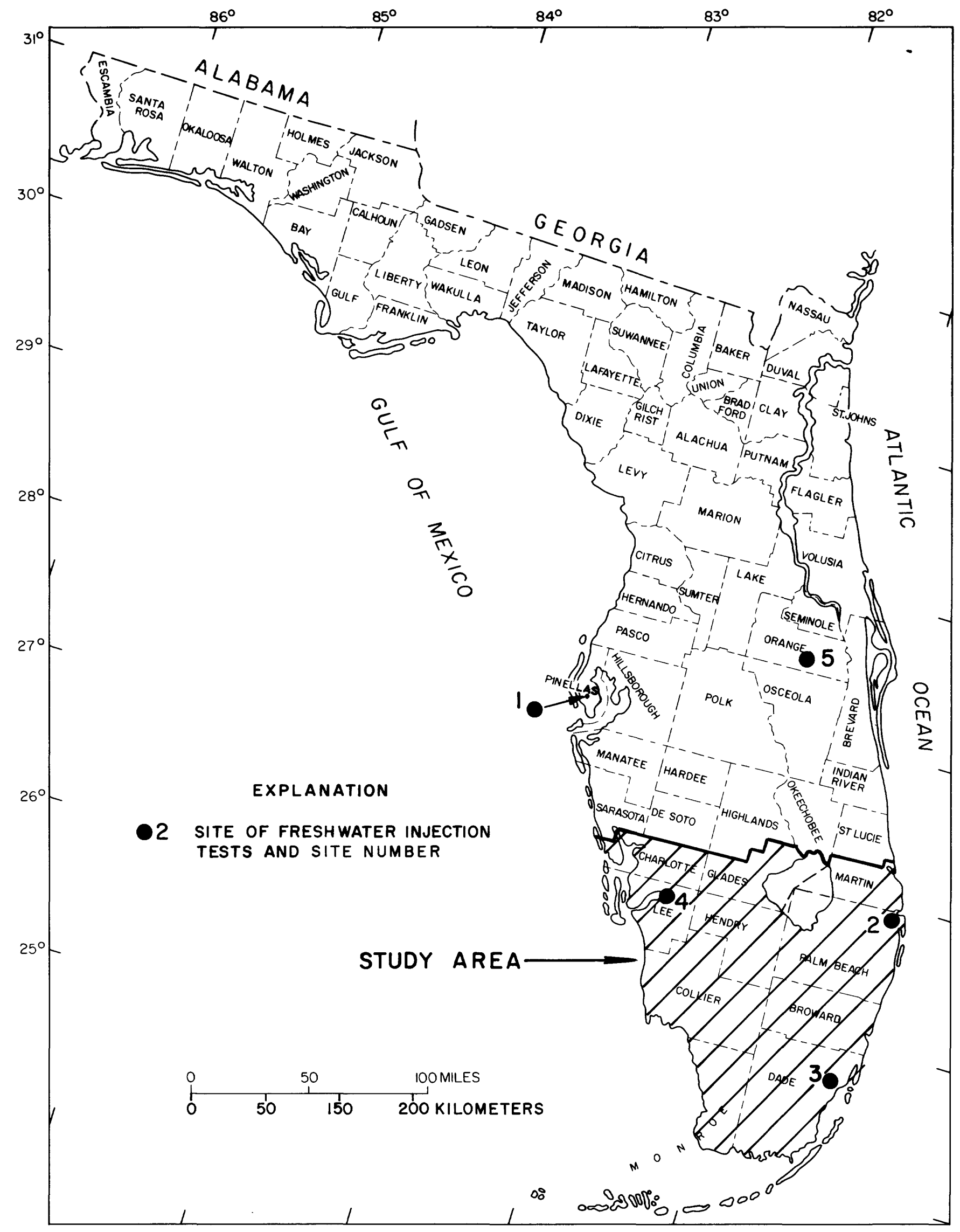

Figure 1.--Study area and locations of freshwater injection tests. 
Injection and recovery tests were conducted at site 3 (fig. 1) at Hialeah in Dade County from $1975-78$ by the U.S. Geological Survey (F. W. Meyer, oral commun., 1980), in cooperation with SFWMD and with the Miami-Dade Water and Sewer Authority. Other operational cyclic injection tests have been conducted at site 4 (fig. 1) near Fort Myers in Lee County by the U.S. Geological Survey (D. J. Fitzpatrick, written commun., 1982). In these tests, water from the Caloosahatchee River was injected into limestone of the Hawthorn Formation. Injection and recovery of freshwater supplied from a secondary artesian aquifer source was accomplished in Orange County (1969-70) by the U.S. Geological Survey (Tibbals and Frazee, 1976).

An investigation into the feasibility of subsurface storage of stormwater runoff was performed in 1974 at site 1 (fig. 1) in Pinellas County for the City of St. Petersburg and the State of Florida Department of Natural Resources (DNR) by Black, Crow, and Eidsness, Inc. (1974). A cyclic injection system was operated by DNR in 1975 near Jupiter in Palm Beach County (site 2, fig. 1) (J. J. Plappert, written commun., 1977). Other injection and recovery tests have recently been conducted by $\mathrm{CH}_{2} \mathrm{M} \mathrm{Hill}$ (D. Pyne, oral commun., 1982) in Manatee County. Tests in St. Lucie County have recently been conducted by SFWMD (Wedderburn and Knapp, 1983).

\section{Acknowledgments}

The support and help of Toney Lanier, U.S. Army Corps of Engineers, Jacksonville, Fla., was invaluable in bringing the products of this study to fruition.

\section{PART I - FRESHWATER-SUPPLY DEFICIENCIES}

The fresh surface-water and ground-water system of south Florida, considered in its entirety, probably contains an adequate amount of potable water throughout the year for present (1983) needs. However, potable water supply at times becomes deficient in certain localities as a result of a combination of two factors: (1) the annual periodicity of natural replenishment of the freshwater system; and (2) problems relating to the timely conveyance of water from where it is available to where it is needed.

The greater part of annual natural recharge usually occurs during the wet season (June to October). Late in the dry season (November to May), water frequent ly must be conveyed to locations where human use outstrips storage and recharge. For example, surface water from inland storage areas is routed by canals to coastal urban areas to protect and replenish the supply of potable ground water. Salinity-control structures on the canals near the coast are closed to maintain high water levels in the canals and underlying aquifers, a strategy to prevent saltwater intrusion. In another example, water is supplied year-round to the Florida Keys through a pipeline from the mainland. The complex water-management system of south Florida (fig. 2) includes many such features and is generally designed to optimize the distribution of available water in all seasons of the year. 


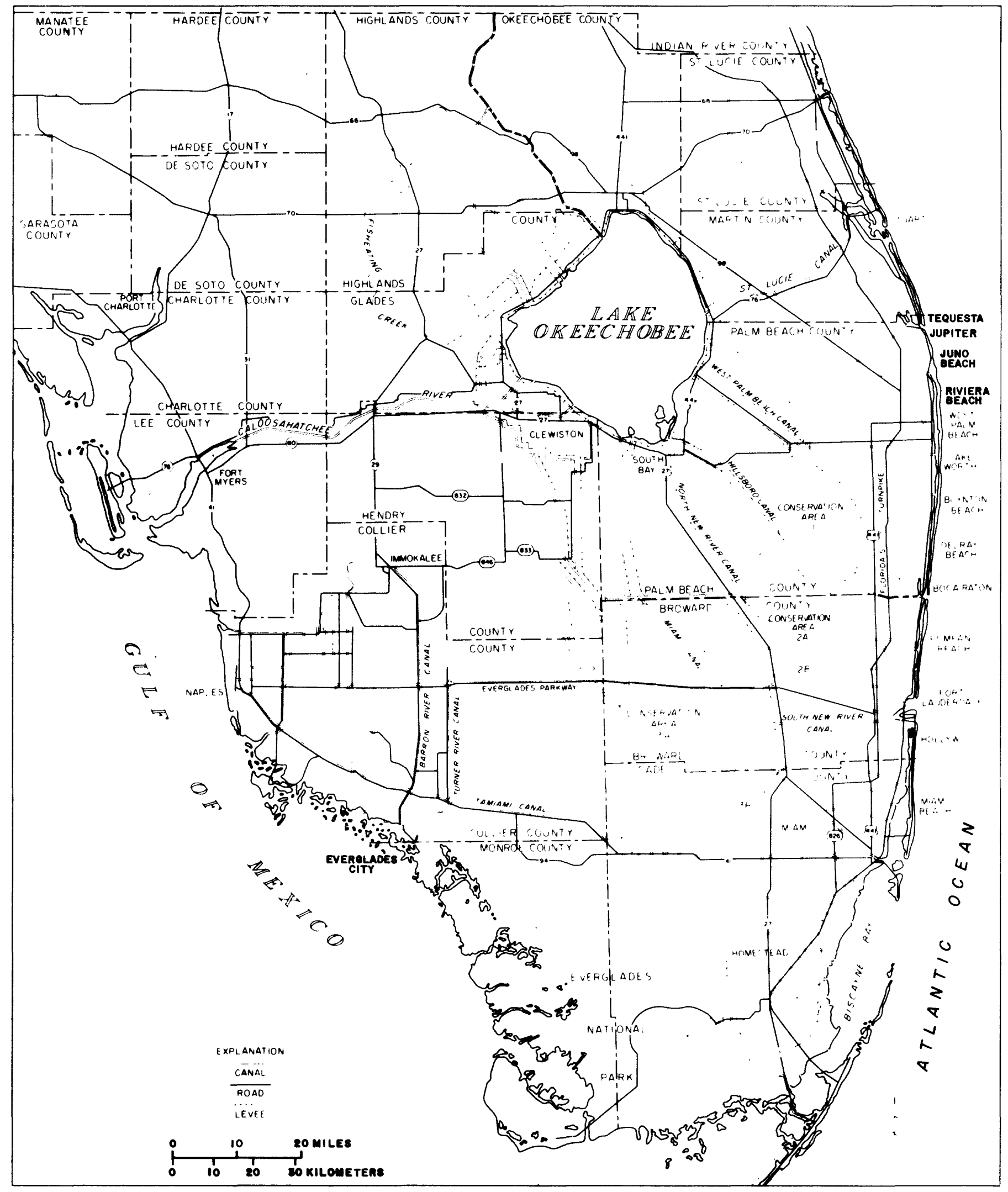

Figure 2.--Major features of the water-management system of south Florida. 
In the foregoing examples, characteristic of south Florida, freshwater deficiencies have become manifest as either the virtually complete absence of natural supply or as the encroachment of saline water into surficial aquifers used for public supply. Saline-water intrusion is often caused by the excessive lowering of water levels by pumping or by canal drainage. Even in the absence of contamination of freshwater supply by saline water, lowered water levels can represent water deficiency if they bring about ecological damage to environmentally sensitive areas.

As water deficiency takes many forms and has a variety of specific causes, water-deficient areas are defined in this study as localities where the supply of potable water tends to be insufficient for some water users during some part of the year. Potentially water-deficient areas are localities where such deficits may occur if water use continues to increase, or if a drought occurs at current levels of water use. This concept of an area characterized by watcr deficiency can be somewhat vague, as water deficiency affects entire systems of water supply and, therefore, applies to large areas served by a common system.

Besides areas with a small natural water supply, water-deficient areas may include localities of large natural supply but even larger water use such as along the east, coast. This is because highly productive aquifers have been heavily used by a large population. Water deficiencies also occur along the relatively lightly populated west coast of south Florida because local aquifers are relatively less productive.

In the 10-county area comprised of Martin, Palm Beach, Broward, Dade, Monroe, Collier, Lee, Charlotte, Glades, and Hendry Counties, 65 percent of the fresh ground-water and surface-water use in 1977 was for agriculture (table 1). Agricultural use dominated in all counties except Dade, Broward, and Monroe. Public supply accounted for 29 percent of the total freshwater use in the 10-county area but was the largest use in Dade, Broward, and Monroe Counties. However, despite the heavy use of freshwater for agriculture in the interior, it is primarily the east and west urbanized coasts where potable water deficiency becomes manifest, usually as saltwater intrusion into municipal well fields. Here, public supply is the major use.

Where deficits occur, possible remedies may include: (1) improvement of conveyance systems for transfer of water to locations of need; (2) full or partial relocation of coastal well fields inland, lessening the threat of saltwater intrusion; (3) desalination; (4) restriction of water use; (5) reclamation of wastewater; and (6) implementation of water-conservation measures for reducing losses to the ocean and to the atmosphere. One conservation alternative is the cyclic injection concept, which refers to the subsurface injection of freshwater when it is available in surplus for later recovery and use when it is needed. Whether cyclic injection is preferred over other alternatives depends upon site-specific hydrologic and economic factors. 
Table 1.--Freshwater use in south Florida during 1977

[From Leach and Healy, 1979; Freshwater use in million gallons per day]

\begin{tabular}{|c|c|c|c|c|c|c|}
\hline County & Water type & $\begin{array}{l}\text { Public } \\
\text { supply }\end{array}$ & Rura 1 & $\begin{array}{l}\text { Indus- } \\
\text { trial }\end{array}$ & $\begin{array}{l}\text { Irri- } \\
\text { gation }\end{array}$ & Total \\
\hline Martin & $\begin{array}{l}\text { Ground water } \\
\text { Surface water }\end{array}$ & $\begin{array}{c}5.51 \\
--\end{array}$ & $\begin{array}{l}3.21 \\
0.10\end{array}$ & 0.10 & $\begin{array}{r}8.22 \\
81.26\end{array}$ & $\begin{array}{l}17.04 \\
81.36\end{array}$ \\
\hline Palm Beach & $\begin{array}{l}\text { Ground water } \\
\text { Surface water }\end{array}$ & $\begin{array}{l}66.07 \\
30.24\end{array}$ & $\begin{array}{r}14.57 \\
1.40\end{array}$ & $\begin{array}{r}2.18 \\
45.43\end{array}$ & $\begin{array}{r}37.92 \\
471.50\end{array}$ & $\begin{array}{l}120.74 \\
548.57\end{array}$ \\
\hline Broward & $\begin{array}{l}\text { Ground water } \\
\text { Surface water }\end{array}$ & $\begin{array}{c}155.85 \\
--\end{array}$ & $\begin{array}{l}3.21 \\
0.44\end{array}$ & $\begin{array}{l}2.98 \\
1.00\end{array}$ & $\begin{array}{l}19.45 \\
60.14\end{array}$ & $\begin{array}{r}181.49 \\
61.58\end{array}$ \\
\hline Dade & $\begin{array}{l}\text { Ground water } \\
\text { Surface water }\end{array}$ & $\begin{array}{c}274.19 \\
--\end{array}$ & $\begin{array}{c}4.13 \\
--\end{array}$ & $\begin{array}{c}6.73 \\
--\end{array}$ & $\begin{array}{r}100.91 \\
2.96\end{array}$ & $\begin{array}{r}385.96 \\
2.96\end{array}$ \\
\hline Monroe & $\begin{array}{l}\text { Ground water } \\
\text { Surface water }\end{array}$ & 7.20 & 0.02 & - & $\begin{array}{c}0.04 \\
-\end{array}$ & $\begin{array}{l}7.26 \\
--\end{array}$ \\
\hline Collier & $\begin{array}{l}\text { Ground water } \\
\text { Surface water }\end{array}$ & $\begin{array}{c}14.12 \\
-\end{array}$ & $\begin{array}{l}0.92 \\
0.45\end{array}$ & - & $\begin{array}{r}72.62 \\
4.82\end{array}$ & $\begin{array}{r}87.66 \\
5.27\end{array}$ \\
\hline Lee & $\begin{array}{l}\text { Ground water } \\
\text { Surface water }\end{array}$ & $\begin{array}{r}12.27 \\
6.74\end{array}$ & $\begin{array}{l}2.79 \\
0.04\end{array}$ & $\begin{array}{l}0.40 \\
8.00\end{array}$ & $\begin{array}{l}70.99 \\
22.50\end{array}$ & $\begin{array}{l}86.45 \\
37.28\end{array}$ \\
\hline Charlotte & $\begin{array}{l}\text { Ground water } \\
\text { Surface water }\end{array}$ & $\begin{array}{l}0.08 \\
3.89\end{array}$ & 1.61 & 0.10 & $\begin{array}{c}20.90 \\
--\end{array}$ & $\begin{array}{r}22.69 \\
3.89\end{array}$ \\
\hline Hendry & $\begin{array}{l}\text { Ground water } \\
\text { Surface water }\end{array}$ & $\begin{array}{l}0.25 \\
1.30\end{array}$ & $\begin{array}{l}4.58 \\
0.90\end{array}$ & $\begin{array}{l}0.25 \\
0.71\end{array}$ & $\begin{array}{r}82.60 \\
204.05\end{array}$ & $\begin{array}{r}87.68 \\
206.96\end{array}$ \\
\hline Glades & $\begin{array}{l}\text { Ground water } \\
\text { Surface water }\end{array}$ & $\begin{array}{c}0.22 \\
--\end{array}$ & $\begin{array}{l}0.55 \\
1.14\end{array}$ & $\begin{array}{r}0.66 \\
21.60\end{array}$ & $\begin{array}{l}12.28 \\
45.78\end{array}$ & $\begin{array}{l}13.71 \\
68.52\end{array}$ \\
\hline Tota 1 & $\begin{array}{l}\text { Ground water } \\
\text { Surface water } \\
\text { A11 water }\end{array}$ & $\begin{array}{r}535.76 \\
42.17 \\
577.93\end{array}$ & $\begin{array}{r}35.59 \\
4.47 \\
40.06\end{array}$ & $\begin{array}{l}13.40 \\
76.74 \\
90.14\end{array}$ & $\begin{array}{r}425.93 \\
893.01 \\
1,318.94\end{array}$ & $\begin{array}{l}1,010.68 \\
1,016.39 \\
2,027.07\end{array}$ \\
\hline
\end{tabular}


The following sections briefly describe the types of water deficiencies that occur locally within each of the ten counties. Many sections begin with a brief description of local water-management systems, highly sophisticated in most counties of south Florida, as one of their purposes is to avert water deficiency and to optimize the availability of water to all users throughout the year. Specific examples are given of critical water deficiencies which have occurred since 1970, by which time most of the present water-management system was in operation. Quantification of the amount of water deficiency is beyond the scope of this report. However, it may be defined conceptually as the difference between need and use during the time period in which the deficit occurs. Projections of amounts of water needed in future years in various parts of the region are to be found in publications of the South Florida Water Management District (1978; 1979).

\section{Martin County}

The primary source of public water supply in Martin County is ground water from surficial aquifers. The city of stuart is the largest municipal user of surficial aquifer water. At times, saltwater has approached supply wells used by the city. At the end of the 1975 dry season, saltwater was about 2,700 feet north and 3,000 feet west of the nearest supply wells at the same depth from which withdrawals were made ( $S$ cott and others, 1977). As the well field is bounded on three sides by saltwater bodies and the only fresh ground-water recharge is from the south, saltwater intrusion remains a hazard whenever large withdrawals are made during periods of low rainfall recharge.

Because surficial aquifers are relatively unproductive inland, most water for agriculture in Martin County is supplied from Lake Okeechobee by a system of canals. However, some saline artesian water has been used for irrigation, causing local contamination of surficial aquifers. Upconing of water of even higher salinity within the artesian zone during pumping has exacerbated the problem. Additional contamination has resulted from leakage through some of these wells into the surficial aquifer (Lichtler, 1960). In times of unusually low rainfall, water deficiencies can affect both inland agricultural and coastal urban water users.

\section{$\underline{\text { Palm Beach County }}$}

The primary source of freshwater in coastal Palm Beach County is the surficial (coastal) aquifer. Recharge to the aquifer in south and central coastal Palm Beach County is augmented by a network of shallow east-west lateral canals and north-south equalizing canals administered by the Lake Worth Drainage District (Land and others, 1973; Scott and others, 1977). Water is pumped into the system from Water Conservation Area no. 1 (Loxahatchee National 
Wild1ife Refuge) from the east, and from the Hillsboro Canal to the south. Control structures to the east maintain high water levels in the agricultural area between the Refuge and the 3 to 4-mile wide urbanized coastal strip. The West Palm Beach Canal to the north does not contribute water to the system and may receive water from the District by ground-water seepage. During the wet season, the canal system provides drainage. Additional canals criss-cross the coastal strip, and control structures near the coastline maintain lower prescribed water levels than in the agricultural area. Major municipal well fields are in the coastal strip, some very close to the sea. Although water levels tend to remain high in most places along the coast because of the relatively low permeability of the surficial aquifer and the high land elevation, saltwater intrusion has occurred locally near well fields (Scott and others, 1977).

During 1970-71 when water levels were particularly low, unusually high tides caused saltwater to top the structure on the E1 Rio Canal at Boca Raton. Saltwater trapped upstream then migrated through the surficial aquifer towards the Boca Raton well field, curtailing the use of several wells. Pumping had to be shifted inland.

The potential for saltwater intrusion exists near Delray Beach and Boynton Beach, where the distance between supply wells and saline surface water is about 2,200 feet. According to Scott and others (1977), saltwater at 150 to 200 feet below sea level is within 1,000 feet of the nearest municipal wells. In contrast, the Lake Worth and Riviera Beach well fields in central Palm Beach County are farther inland at a relatively safe distance from saline sources (Scott and others, 1977). The city of West Palm Beach in the central part of the county has avoided the problem of saltwater intrusion into wells, because its water is obtained from clear Lake which is replenished by canal flows from inland areas.

The greatest degree of saltwater intrusion into coastal well fields occurs in northeast Palm Beach County outside the Lake Worth Drainage District (Scott and others, 1977). Both the Juno Beach and Tequesta municipal well fields are near saline surface-water bodies. The distance between saline surface water and the nearest supply well is 1,400 feet in the Tequesta well field and 1,900 feet in the Juno Beach well field (Scott and others, 1977). At the end of the 1975 dry season, the distance from saltwater to the bottom of the nearest supply well in the Juno Beach well field was 1,000 feet, and saltwater had reached the nearest supply well in the Tequesta well field. Near the end of the 1970-71 drought, saltwater contamination necessitated a reduction in pumping from the Jupiter well field. 
The largest amounts of water used in Palm Beach County (table 1) are for agricultural purposes in the interior part of the county. Very substantial amounts of acreage are used for raising sugarcane, while lesser, but still substantial amounts of acreage are used for truck farming or as pastureland. Agricultural water needs are supplied chiefly from Lake Okeechobee, as surficial aquifers inland are not sufficiently productive and contain saline water in some parts of the area. Water is moved from the lake into the primary canal systems from which part is diverted into secondary canals and irrigation ditches from which withdrawals are made. During long dry periods, the needs of agricultural and coastal urban users could peak at a level exceeding the amount obtainable from the lake, necessitating water-management decisions to insure that potable water deficiency is shared appropriately by all users.

\section{Broward County}

In coastal Broward County, public water supply is from the surficial aquifer (the Biscayne aquifer system), considered to be the sole source for the area. Well fields were developed decades ago in populated areas near the coast when population and water use were far less than they are today. As a result of the current increased level of water use, deficiency of freshwater supply now occurs at times as saltwater intrusion into the coastal well fields during the dry season.

Water levels are near sea level in many areas along the coast drained by uncontrolled tidal reaches of canals and by networks of finger canals. Dry season water levels are near sea level further inland in areas drained by the Middle River, North New River, South New River, and Hollywood Canals (locations illustrated by McCoy, 1973a) because control structures on these canals are about 4 to 7 miles inland. As a result, some coastal well fields are near tidal reaches of nearby canals.

During low rainfall periods, heavy pumping can cause a reversal of the normal slight seaward hydraulic gradient and diversion of saline water from the tidal reach toward public-supply wells. Such conditions prevailed during part of the 1970-71 dry period. Between the Prospect well field near Fort Lauderdale and the tidal reach of Middle River Canal, water levels dropped to such an extent that, for a short time, the hydraulic gradient was toward the well field (McCoy, 1973a). Recurrence of the situation was prevented by the construction of a feeder canal to transport freshwater from the controlled reach of the Middle River Canal to recharge the well field and by shifting pumping to wells farther inland. 
During the same dry period, a similar situation affected the Dixie well field north of the tidal reach of the North New River Canal. Water levels in the southern end of the well field were below sea level, while those between the well field and the salty reach of the canal declined to near sea level. Saltwater contamination was averted by shifting pumping from wells in the southern part of the well field to wells in the northern part distant from the canal.

A threat of saltwater intrusion might exist in the vicinity of the Hollywood well field, because much of the Hollywood Canal is uncontrolled and serves as a conduit for saltwater to move inland. Near the end of the 1971 and 1972 dry seasons, when canal discharge and runoff into the canal were low, saltwater penetrated far inland and infiltrated the aquifer, coming within $0.1 \mathrm{mile}$ of supply wells in the northern part of the well field in 1971 (Bearden, 1974c) and to within 0.15 mile of supply wells in the southern end of the well field in 1972. Similarly, the Hallandale well field is only 2 miles west of the saline Intracoastal Waterway. During May 1970, saltwater was estimated to be within $0.3 \mathrm{mile}$ of the well field (Bearden, 1974c).

In the Pompano Beach area, the uncontrolled finger canals that dissect the area east of U.S. Highway 1 continually drain ground water from storage, lowering the water table (Tarver, 1964). In May 1971, water levels between the well field and the Intracoastal Waterway were near sea level (Bearden, 1973). During the 1975-76 dry season, a reduction in pumpage from wells in the southern end of the well field was necessary. In Deerfield Beach, along the tidal reach of the Hillsboro Canal, the occurrence of saltwater as far upstream as the control dam is not uncommon.

As in Palm Beach County, irrigation water for agriculture is supplied by conveying water from Lake Okeechobee through a system of canals. During an extended dry season, priorities might have to be established in sharing water deficiencies between agricultural interests and coastal urban areas.

\section{Dade County}

As in Broward County, public water supply in coastal Dade County is obtained from the sole source Biscayne aquifer system, and well fields were developed near the populated coast in times when population and water use were far less than they are today. Nevertheless, saltwater intrusion is a localized problem. Salinity-control structures in canals along most of the urbanized coast of Dade County, where inland land elevations are low and the surficial aquifer very permeable, are generally within $1.5 \mathrm{miles}$ of the ocean, restricting inland encroachment of saltwater toward well fields. A significant exception are the controls on the Miami, 
Tamiami, and Coral Gables Canals about 5 miles inland and downgradient from the Hialeah-Miami Springs well field, until recently the largest in south Florida. Historically, saltwater intrusion has been a threat to the well field. With the construction of the S-25B control structure on the Tamiami Canal in 1976, water levels behind the three control structures have recently been maintained more than 2 feet above sea level, driving the saltwater wedge back toward the tidal reaches of the Miami and Tamiami Canals ( $K$. W. Ratzlaff, oral commun., 1982). However, increasing pumpage from the well field raises the eventual possibility that saltwater might intrude around the control structures. The control structure on the Coral Gables Canal is also quite far inland, $4 \mathrm{miles}$ from the ocean, allowing saltwater that could intrude into the aquifer to enter the tidal reach during low rainfall periods.

In response to increasing demand for water, the Northwest we 11 field, with a capacity even greater than that of the Hialeah-Miami Springs well field, was recently (1983) opened west-southwest of Hialeah. A 9-mile, 96-inch pipeline extends from the well field to the Hialeah water-treatment plant.

In Dade County, the extent of saltwater intrusion around coastal control structures increases southward. There has been insufficient water to maintain high water levels in south Dade County canals because the predevelopment southward regional flow has been diverted eastward for use by urban areas to the north. Saltwater has intruded along the west side of U.S. Highway 1 south of Florida City and east and south of Homestead Air Force Base. During 1974-75, several water-supply wells in the airbase well field were abandoned because of saltwater contamination. The south Dade County situation may have been partially remedied with construction in 1980 of the south Dade County conveyance system, which is designed to increase the supply of water to south Dade canals.

Water-supply deficiency can also be caused by the contamination of surficial aquifer water by spills of industrial chemicals. Although such incidents have occurred in Dade County, the consequent effects have been highly localized. However, if infiltration of chemical contaminants were to occur upgradient of one of the major well fields, the potential impact upon water supply would be far-reaching. In 1982, the Medley well field, located in an industrial. area and used to supplement supply from the larger HialeahMiami Springs well field, was closed for this reason.

\section{Monroe County}

Potable water deficiency in Monroe County is manifest as a virtually complete absence of local supply, and most of the water used is conveyed there by pipeline. A pipeline from a well field in southern Dade County extends through the Florida Keys to Key West. Water obtained from wells in the freshwater part of Everglades National Park is conveyed by pipeline to Flamingo on the shore of Florida Bay. Public water supply in the Keys is supplemented by potable water obtained by desalination. 


\section{Collier County}

U.S. Geological Survey investigations into hydrologic conditions in Collier County have been summarized by Klein (1980). McCoy (1962) indicated that the Naples area is vulnerable to saltwater contamination from the Gulf, Naples Bay, Gordon River, and salty ground water in the surficial aquifer east and north of $\mathrm{Na}$ ples. According to consultants for the city of Naples, withdrawals of more than $20 \mathrm{Mgal} / \mathrm{d}$ during the dry season would lower water levels between the well field and the coast to a level that would cause saltwater intrusion (McCoy, 1972). Water levels in the lower pumping zone of the aquifer in May 1974 showed the hydraulic gradient on the west side of the well field to be inland from the Gulf (McCoy, 1975). Periodic analyses of the chloride concentration of water from monitor wells in the vicinity of the well field suggest slight inland migration of saltwater from the Gulf and Gordon River during long dry periods when municipal pumping is maximum.

Under the influence of heavy pumping during dry periods, residual mineralized water east of Naples could migrate westward, as occurred during the 1970-71 drought, contaminating municipal supply wells (McCoy, 1972). A possible source of the mineralized water is artesian water from the Floridan aquifer that may leak upward under high pressure where the confining materials are thin or slightly permeable. Upward leakage might also occur through open well bores or corroded casings of artesian wells (Sproul and others, 1972). Upward leakage would tend to increase with drawdowns in the surficial aquifer caused by municipal pumping during dry periods. To avoid saltwater intrusion and to satisfy increasing demands, the city of Naples has established a new well field about 15 miles inland in the Big Cypress Swamp.

In Everglades City on the southwestern coast of the county, McCoy (1962) reported that the chloride concentration of artesian water serving the community had been increasing. Even though pumping was later restricted, the increase continued thereafter to the extent that the chloride concentration eventually exceeded the maximum considered potable according to public health standards. Recently, a new well field has become operational near Copeland north of U.S. Highway 41 , and the community has discontinued use of the old well field. The new wells tap the nonartesian Ochopee Limestone Member of the Tamiami Formation (P. J. Gleason, oral commun., 1983), and water is delivered by pipeline to Everglades City.

In western Collier County, lowered water levels may be another manifestation of water deficiency. A major part of the canal system was begun in the early 1960's with the construction of the Golden Gate Canal and its secondary connector canals. The system serves as the principal drainage in the western part of the county. Construction began in 1968 on the Fahka Union Canal System which now serves as the principal drainage in the southeastern part of the county. By lowering peak annual water levels during the rainy 
season through controlled drainage, these two canal systems enable development of areas east of Naples that had previously remained inundated throughout most of the year. When water levels are high, water moves from aquifer storage into the canals and downstream over a series of weirs. As water levels near the upstream reaches of the canals decrease, the flow of water over the inland weirs ceases, although flow continues at the coastal weirs. In this way, the system is designed to prevent overdrainage and the excessive lowering of inland water levels.

However, in recent years, concern from an environmental standpoint has developed, as parts of the Big Cypress Swamp have undergone ecological changes because of lowered water levels. During most of the year, a decreasing hydraulic gradient causes flow from the Fakahatchee Strand, an environmentally sensitive Area of Critical State Concern, toward the Fahka Union Canal system (Swayze and McPher3on, 1977). Various alternative redevelopment plans are now under consideration (U.S. Army Corps of Engineers, 1980).

\section{Lee County}

Lee County, an area of rapidly expanding population and development, faces continually increasing demands for potable water. The principal sources of ground water have been the surficial aquifer, the uppermost part of the Tamiami Formation, and the upper part of the Hawthorn Formation (0'Donne11, 1977). Limited quantities of salty water are withdrawn from the lower part of the Hawthorn Formation and the Suwannee Limestone beneath.

Water for the city of Fort Myers is pumped from wells that tap the surficial aquifer at depths between 24 to 44 feet ( 0 'Donne11, 1977). This relatively thin aquifer is of limited areal extent. Before 1967, water levels near the well field fluctuated nearly 9 feet between wet and dry seasons. During the dry season, the large drawdowns due to pumping increased the likelihood of upward leakage from underlying saline artesian zones and of saltwater intrusion near the coast. Since 1967, water has been pumped from the controlled reach of the Caloosahatchee River through a 12-mile pipeline into a series of spreading ditches and depressions in the vicinity of the well field, providing artificial recharge of the surficial aquifer by infiltration. Water-level fluctuations since 1967 have been reduced to 4 feet, increasing well-field capacity during periods of peak demand.

However, during extended dry periods, the water available from the Caloosahatchee River can be of poor quality. Slugs of salty water intrude into the controlled reach of the river as a result of boat lockages (Klein and others, 1974). In April 1968, water of $250 \mathrm{mg} / \mathrm{L}$ chloride concentration extended 5 miles upstream of the control structure. At times during the year, nutrient loading of the river and the consequent algal blooms increase the amount of suspended organic matter in the water. 
The quality of the river water is of even greater significance for the Lee County water system, which obtains much of its supply directly from the river. The river water is augmented by water withdrawn from a shallow artesian aquifer, but the productivity of this source is limited. A proposal under consideration by Lee County is to use the shallow artesian aquifer for public supply for the entire year, and to use surficial aquifer water, also of limited availability, for injection during the wet season for later withdrawal and use during the dry season. Experimental cyclic injection tests have been performed by the U.S. Geological Survey to test the feasibility of this alternative (D. J. Fitzpatrick, written commun., 1982). Another alternative is to pump water from the surficial aquifer during the dry season to augment the supply from the shallow artesian aquifer.

The supply of good quality water in Lee County has also been affected by the intrusion of saline ground water into the upper Hawthorn aquifer. Sproul and others (1972) state that upward flows of salty ground water into the upper Hawthorn aquifer through open bore holes of wells penetrating the lower Hawthorn and Suwannee aquifers at times exceed $100 \mathrm{gal} / \mathrm{min}$. Large numbers of these leaking wells could contaminate major sections of shallow aquifers (Boggess, 1968). Also, as water levels in the upper Hawthorn, Tamiami, and surficial aquifers are further reduced by increased pumpage, upward leakage will increase. Water levels near the Cape Coral well field, which taps the upper Hawthorn aquifer, show a downward trend. In some parts of the county, increasing pumpage has lowered upper Hawthorn water levels to 60 feet below land surface (O'Donnel1, 1977) in wells which flowed at land surface prior to development. Water levels in the Tamiami Formation have also been lowered by pumpage, though the annual decline does not appear to be progressive (Missimer and O'Donne11, 1975).

\section{Charlotte County}

Fresh surface water in Charlotte County tends to become deficient in quantity during the dry season when it is also subject to degradation in quality. Most water for public supply is obtained from impounded reaches of local streams that are generally inadequate as reservoirs. Nearly 60 percent of the annual rainfall occurs from June through September, providing more runoff than can be stored in the impounded reaches (Sutcliffe, 1975). In contrast, during extended periods of little or no rainfall, withdrawals may nearly exceed their combined inflow and storage capacity. The climate fosters lush growth of aquatic plants which clog drainageways and cause taste and odor problems.

Some water for public supply and most irrigation water is obtained from the surficial aquifer and shallow (less than 500 feet below land surface) artesian aquifers. The amount available has been reduced by saline-water intrusion from the sea and from underlying saline artesian aquifers. Construction of tidewater canals has resulted in the lowering of water levels in the surficial aquifer in some areas along the coast and the consequent intrusion of saltwater (Sutcliffe, 1975). 
In the southern and western parts of Charlotte County, water levels in brackish shallow artesian aquifers are generally above land surface. In addition, these zones are generally more productive than the surficial aquifer. Where the salinity of the water is within the tolerance level for crops, these factors have encouraged the construction of wells into the artesian zones to obtain irrigation water during the dry season under the assumption that saline water entering the soil zone would be partly flushed by rainfall recharge during the wet season. However, saline water flowing from uncapped artesian wells or leaking into the watertable zone through short-cased wells or corroded well casings has caused the persistent intrusion of saline water into the surficial aquifer in many areas, reducing the amount of freshwater available for public supply in the surficial aquifer.

\section{Hendry County}

Irrigation is the principal water use in Hendry County (table 1). Substantial acreage around Lake Okeechobee is used for growing sugarcane. Further from the lake, large areas are used as pasturelands. In the $1960^{\prime} \mathrm{s}$, agricultural interests and homeowners began to use the surficial aquifer instead of artesian aquifers as a source of water. Artesian water had the advantage of flowing freely at land surface, thus, eliminating the cost of pumping, and the disadvantage of being saline. When distributed over a large area, it infiltrated the surficial aquifer and contaminated the potable water supply (Boggess, 1968). Although rainfall recharge tends to flush saline water from the surficial aquifer in most areas, some of these artesian wells continue to cause persistent contamination of the surficial aquifer by infiltration of free-flowing water and by leakage along casings or through corroded casings (J.E. Fish, oral commun., 1982). Also, the flushing process has been slow in areas where the permeability of the surficial aquifer is low.

More than 80 percent of Hendry County wells inventoried in a recent survey tapped the surficial aquifer (Fish and others, 1983). The surficial aquifer is generally much less permeable than the artesian aquifers, and its productivity, like its lithology, shows considerable areal variability (J. E. Fish, oral commun., 1981). This poses difficulties for agricultural and urban development planning, in that uncertainties about the available water supply must first be resolved. Where the permeability is low, heavy pumping can cause water levels to drop below the pumped zone. Cyclic injection, using captured wet season surficial runoff or Caloosahatchee River water, might prove advantageous for localities of deficient surficial aquifer water supply.

Flowing or leaking artesian wells have contaminated the surficial aquifer at La Belle (Klein and others, 1964). Potable water supply was obtained by constructing a well field outside the city, away from the influence of public-supply wells improperly drilled into the saline artesian zones. 


\section{Glades County}

The principal use of water in Glades County is agricultural. Currently, most irrigation water is pumped from the relatively lowyielding surficial aquifer, but high-yielding, free-flowing artesian water has been used in the past. In the northern part of Glades County, artesian water is not highly mineralized, and chloride concentrations of less than $100 \mathrm{mg} / \mathrm{L}$ have been reported (Klein and others, 1964). The chloride concentration of artesian water increases southward and southeastward. This has led to some contamination of the surficial aquifer by irrigation water in the southern part of the county, and free-flowing or leaking artesian wells continue to contaminate the surficial aquifer in certain localities (Howard Klein, oral commun., 1982).

\section{PART II - AVAILABILITY OF SURPLUS FRESHWATER}

The fresh surface-water and ground-water system of south Florida is replenished primarily by rainfall recharge, 70 percent of which occurs during the wet season (June to October) (Leach and others, 1972). Average annual rainfall at 140 stations along the southeast coast from Jupiter to Homestead over a 33-year period ranged from 56 to $62 \mathrm{in} / \mathrm{yr}$ (MacVicar, 1981). Discharge of freshwater occurs by ground-water flow to the ocean (mainly through surficial aquifers), by surface runoff to the ocean (most of which is controlled river and canal discharge), and by evapotranspiration to the atmosphere. Most canal discharge is restricted by watermanagement practice to the wet season when replenishment of surface water occurs in excess of the storage capacity of the water-management system. Natural ground-water discharge occurs year-round but is greatest during the wet season when ground-water levels are highest. It occurs along most stretches of the south Florida coast but is diminished in the vicinity of large municipal well fields, where some of it is intercepted for public supply. Combined public, private, agricultural, and industrial water users capture a small part of the total ground-water outflow and surface-water discharge.

Diverting for later use some part of the total ground water and canal outflow to the ocean would probably rectify all foreseeable water deficiencies in south Florida, if the water could be conveyed at reasonable cost to where it is needed when it is needed. If 60 inches of rain fall on the $12,308 \mathrm{mi}^{2} 10$-county area each year, and 20 percent ( 12 inches) is not returned to the atmosphere by evapotranspiration, then $2.57 \times 10^{12}$ gallons $\left(3.43 \times 10^{11} \mathrm{ft}^{3}\right)$ recharge the surface-water and ground-water system. This does not include water imported from outside the area such as inflow to Lake Okeechobee from the north. The estimated total freshwater used for al1 purposes in 1977 ( $t a b l e ~ 1)$ was $2.03 \times 10^{9}$ gallons, a very small proportion of the estimated total yearly recharge. Thus, considered as a whole, the fresh surface-water and ground-water system 
likely contains sufficient surplus for conservation practices such as cyclic injection. The problem of water availability becomes a matter of resolving these questions: (1) when is it available? (2) where and from what source is it available? (3) in what quantity is it available at a given location? (4) is its quality satisfactory at a given location where it is available? and (5) is it near a water deficient area or is there a suitable conveyance system from where it is available to where it is needed?

Injection of surplus freshwater would likely be done during the wet season when the quantity available in any part of south Florida is at its peak. The remaining questions are most accurately answered on a site-specific or problem-specific basis because of the complexity of the surface-water and ground-water system and the pattern of its management and use. The following sections discuss considerations involved in resolving each of these issues.

\section{Sources}

Surplus freshwater can be obtained from the surficial or shallow artesian aquifers that are present in most of south Florida, and from deeper artesian aquifers that contain freshwater along the northern limits of the study area. During the wet season, surplus freshwater might even be obtained from well fields near the coast, where during the dry season, saltwater intrusion might be a problem caused by heavy pumping. In the western part of the study area, aquifers are relatively less productive than those along the east coast and are used on a smaller scale, but the dry-season water needs of coastal urban areas are also less. In the larger Florida Keys, it is possible that temporary lenses of fresh ground water formed during periods of heavy rainfall might provide adequate amounts in excess of immediate needs which might thereby be used for injection. The surplus water might be obtained from shallow wells or from drainage and collection systems.

Surface freshwater is usually in surplus during the wet season. In a normal wet season, reservoirs such as Lake Okeechobee and the conservation areas receive rainfall recharge in excess of their storage capacity, and surplus water is conveyed to coastal discharge points by rivers and canals or is discharged into Everglades National Park. Water for injection might even be made available in locations remote from reservoirs or major conduits by the construction of drainage ditches to intercept surface runoff and some water infiltrating the soil.

Water-use amounts for 1977 ( $t a b l e ~ 1)$ illustrate the degree to which various freshwater sources are used and suggest that appreciable quantities of surplus water might be available from them. The large quantities of surface water from Lake Okeechobee and the water-conservation areas used by agriculture and agriculturally related industry in Martin, Palm Beach, Broward, Hendry, and Glades 
Counties comprised 46 percent of freshwater used in the 10-county area. Another 28 percent was ground water from the Biscayne aquifer in Dade and Broward Counties, primarily used for public supply and irrigation. These figures show the significance of Lake Okeechobee, the water-conservation areas, and the Biscayne aquifer as major sources of water in south Florida, and perhaps as primary sources of freshwater for injection during the wet season. On the other hand, 15 percent of the total freshwater used was withdrawn from the relatively low yielding aquifers of Collier, Lee, Charlotte, Hendry, and Glades Counties, primarily for irrigation. This illustrates the substantial capacity of low yield aquifers as sources of water when pumping wells are distributed so that drawdowns are not sufficient to cause upward leakage from saline artesian aquifers or to cause lateral migration from nearby saltwater bodies. It might also suggest that west coast surficial or shallow artesian aquifers could provide substantial amounts of water for freshwater injection during the wet season.

\section{Quantity}

Quantification of the amount of surplus freshwater which can be made available for injection during the wet season is a task which should be addressed in the context of proposals for injection and recovery systems at designated sites. Making a reliable estimate at a designated site will require analyses of available ground water and available surface water, their interrelation, and the extent and effects of various types of human water use. Furthermore, estimates are usually based upon long-term statistics, and the surplus available in a given year can vary substantially.

To undertake such evaluations comprehensively on an areawide basis would require a costly program of data collection and a major commitment of personnel in order not to produce results of such generality that they might not be applicable with any acceptable degree of accuracy to a designated site. Thus, this report does not present numerical estimates of total available surplus freshwater in every part of south Florida. Rather, the following discussion evaluates the significance of coastal and inland discharge data, the only known quantitative measurements of surplus freshwater in the area, and suggests ways to obtain surplus freshwater estimates at designated sites.

Quantities of surface water discharged through coastal control structures and by way of controlled and uncontrolled surface flow into Everglades National Park represent excess surface storage modified along the conveyance reach by human uses, surface runoff, infiltration into and accretion from ground water, and evapotranspiration. It is only part of the discharge from the water system, as unquantified amounts of fresh ground water in surficial aquifers discharge into the sea or seep into Everglades National Park. Not all of the controlled discharge or ground-water outflow should be 
considered divertible for freshwater injection or other use, as part of the flow in certain canals may need to be maintained for the ecological balance of downstream estuaries, such as, for example, the lower part of the Caloosahatchee River. A minimum requirement of surface inflow each year $\left(1.13 \times 10^{10} \mathrm{ft}^{3}\right)$ is prescribed for the proper environmental management of Everglades National Park. In some recent wet seasons, the park has received excessive amounts of controlled and uncontrolled discharge from north of the Tamiami Trail, curtailing some park activities.

Discharge data were available from 23 control structures on the east and west coasts of south Florida, as well as for 4 reaches of the Tamiami Canal (fig. 3). Discharge data were unavailable for seven other control structures on the east coast. Average discharge amounts for the 11-year period (1970-81) (table 2) show that an average total of $1.89 \times 10^{11} \mathrm{ft}^{3}$ flow each year through the Tamiami Canal Outlets and through the coastal control structures for which data were available. This is about half of the previously cited estimate of total annual recharge from rainfall $(3.43 \mathrm{x}$ $10^{11} \mathrm{ft}^{3}$ ) and represents a large part of the total ground and surface discharge from the water system, which includes water imported from outside the area.

Table 2 shows for each site the discharge magnitude exceeded $10,25,50,70,75,90$, and 95 percent of the time during periods of highest discharge from 1970-81. The values were provided by W. H. Sonntag (written commun., 1981), who also provided tables showing the maximum, minimum, and mean discharges for high discharge periods from 1970-81. The normal period of high discharge does not correspond exactly to the standard wet season (June to October) at every site because of varying water-release practices.

Discharges as high as $330 \mathrm{ft}^{3} / \mathrm{s}$ are exceeded 70 percent of the time at some coastal control structures such as those in the $\mathrm{Ca}$ loosahatchee River and Golden Gate Canal. At other structures (those in the Biscayne, Plantation Road, Middle River, and Cypress Creek Canals), on the other hand, appreciable discharge (more than $0.1 \mathrm{ft}^{3} / \mathrm{s}$ ) occurs less than 70 percent of the time during the high discharge period, and at one (Canal $\mathrm{C}-111$ ) appreciable discharge occurs less than 50 percent of the time (table 2). At 8 coastal control structures, outflow exceeds a discharge magnitude of 10 $\mathrm{ft}^{3} / \mathrm{s} 95$ percent of the time during the high discharge period of each; at 11 structures, outflow exceeds $10 \mathrm{ft}^{3} / \mathrm{s} 90$ percent of the time.

Large quantities of water are discharged into Everglades $\mathrm{Na-}$ tional Park through the Tamiami Canal Outlets. More than $370 \mathrm{ft}^{3} / \mathrm{s}$ flows across the Monroe to Carnestown reach 70 percent of the time from July through 0ctober; more than $200 \mathrm{ft}^{3} / \mathrm{s}$ flows across the 40Mile Bend to Monroe reach 70 percent of the time during the same period. From Levee 67A to 40-Mile Bend, flow into the park exceeds $660 \mathrm{ft}^{3} / \mathrm{s} 70$ percent of the time from September through December. 


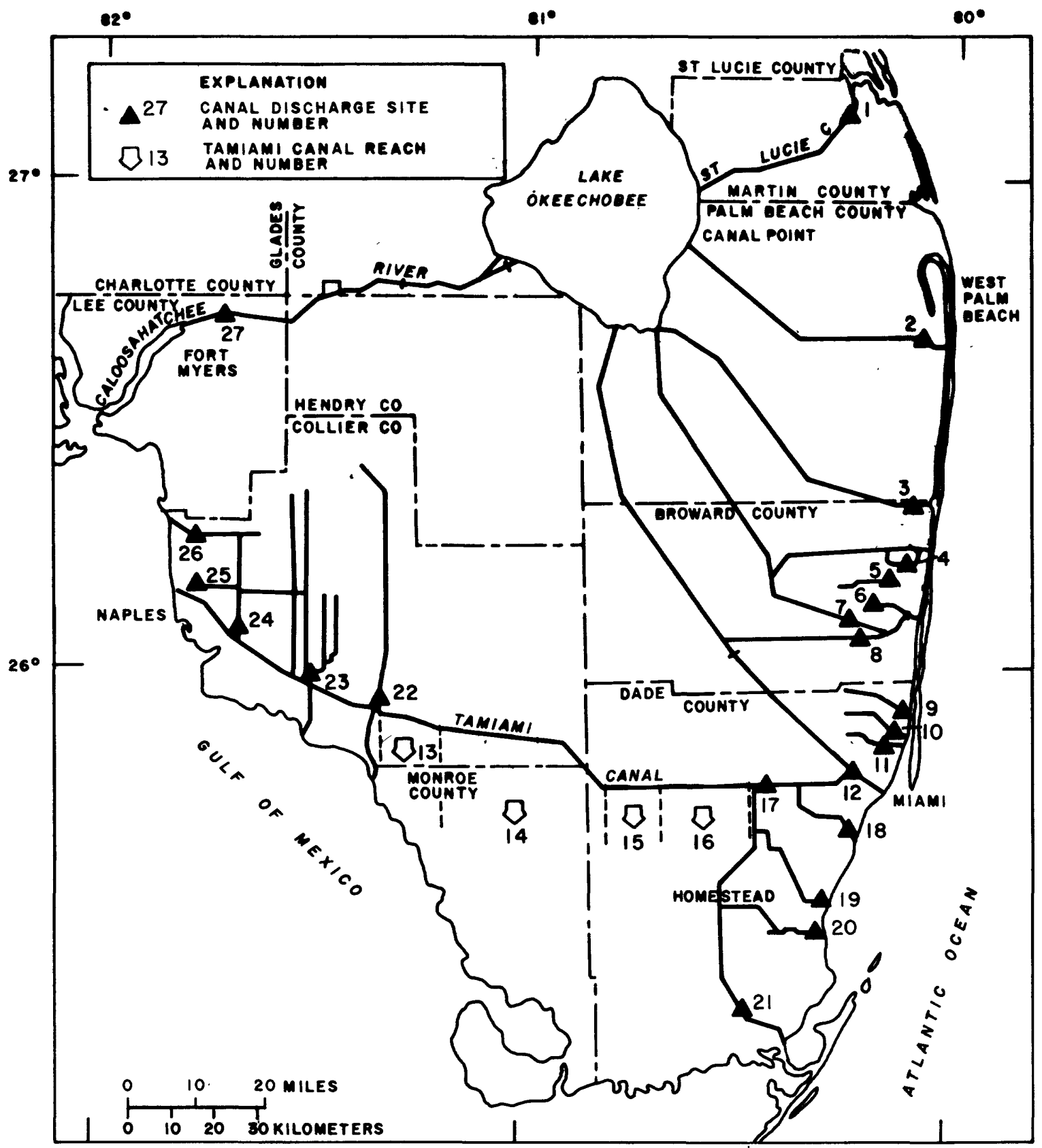

Figure 3.--Sites in south Florida where controlled or uncontrolled surface discharge from the water-management system is measured. 


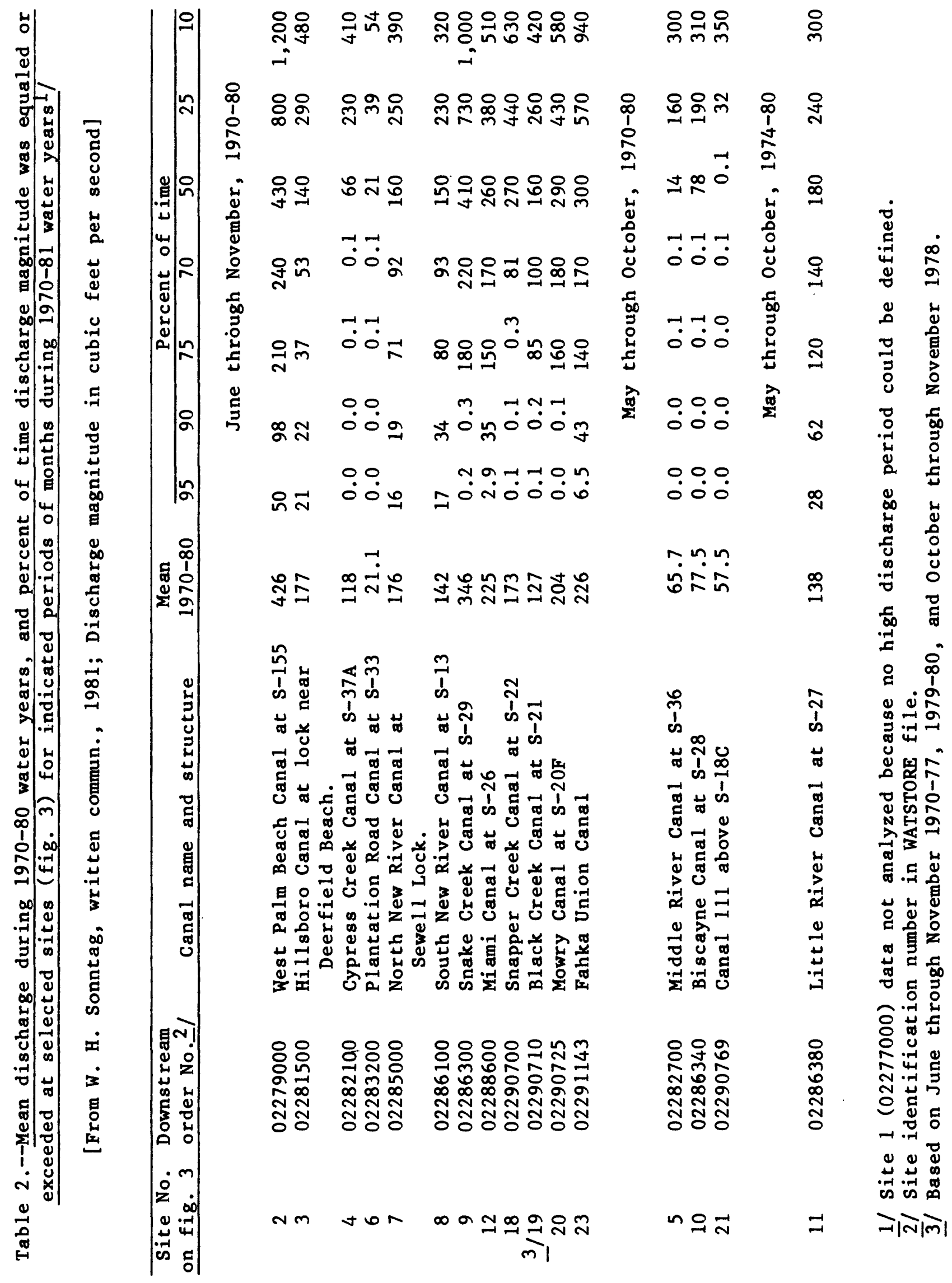




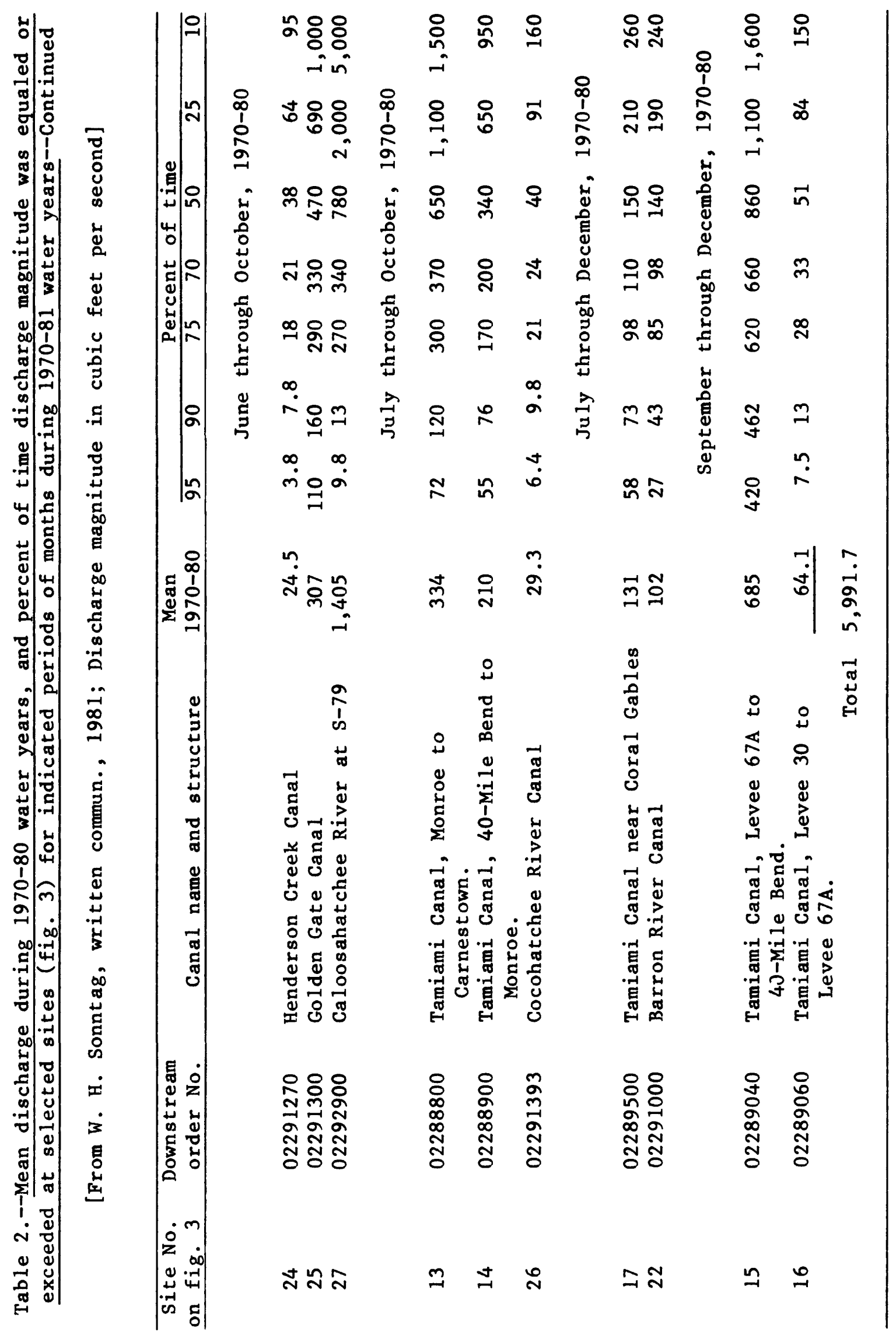


Some coastal control structures are not far downstream of wel1 fields and water-treatment facilities. Stage-discharge relations can provide real-time measurements of outflow that can be compared with the long-term discharge statistics to predict whether the long-term average is likely to be met or exceeded. If the amount of freshwater outflow needed to maintain the hydrologic and ecologic balance of coastal estuarine areas can be quantified, the remainder can generally indicate the amount of canal water available for injection in the vicinity of the nearby well field. It is not a direct measure, however. For example, diversion of substantial water from the canal above the well field and the consequent lowering of canal stage would reduce recharge to the well field. Furthermore, some water discharged at the control structures might be runoff accretion along the reach below the well field. The water needs of Everglades National Park can be compared in similar fashion with average amounts discharged across the Tamiami Trail, or with an estimate of amounts likely to be discharged in a given year, to determine probable amounts available for subsurface storage.

Surplus freshwater estimates at locations distant from rated coastal discharge control structures will require site-specific water budget analyses of acceptable accuracy based upon the avai1able data. Extrapolation of coastal canal discharges to upstream locations must take into account the accretion or dimunition of flow from natural or manmade causes in intervening reaches. Canal discharges at the coast do not provide surplus freshwater estimates at coastal or inland locations distant from the canals and do not measure the amounts of surplus ground water available anywhere. However, surplus canal water and ground water in the vicinity of well fields are related, in that some water withdrawn by extra pumping to supply an injection system would be replaced by additional canal water recharging the aquifer in the vicinity of the well field.

Estimates of wet-season surplus ground water from surficial aquifers will probably require computer simulations incorporating local hydraulic properties and recharge and discharge (rainfall, evapotranspiration, canals, and we11s). If ground water is used, it is likely to be obtained and injected near well fields because of the proximity of established water-treatment facilities. A decision to use ground water might be based on its superior quality. Surplus canal water in the vicinity would then recharge the well field from which the ground water is obtained. The computer simulations would be used to determine maximum safe yield during the wet season, taking into consideration hydraulic gradients between the well field and any nearby saltwater bodies.

Criteria for amounts of surplus freshwater considered adequate to support injection systems cannot be established in general, as they would vary greatly with water needs to be satisfied and with the efficiency of a particular injection system. However, from the foregoing discussion, it appears that substantial amounts of surface water are available at some of the measured discharge locations. The availability of surplus fresh surface water or ground water should be established at designated sites when they are chosen. 


\section{Quality}

The chemical composition of water to be injected is important from two standpoints: (1) its effect upon the injection process; and (2) use of the recovered water. Injected water can interact physically, chemically, or biologically with both the native water and the rock formations into which it is injected (Vecchioli and others, 1974). Typical physical interactions are heat exchange and the plugging of rock pores by suspended solids. Typical chemical reactions may cause dissolution of the aquifer matrix, precipitation of solids, ion exchange or adsorption, or oxidation and reduction of substances. A typical biological process is the growth of micro-organisms.

Perhaps the interactive process of greatest concern from the standpoint of freshwater injection is the plugging of pores in the aquifer, which reduces permeability and means that higher pressures are required to inject less water. Plugging occurs when the injected water has a high suspended solids content, or acquires it as a result of chemical reactions or biological processes during injection or while in storage in the aquifer. Injection of water containing high dissolved ion concentrations can cause the formation of precipitates which act as suspended solids. Algae present in the injected water may also act as a suspended solid. Iron bacteria can cause the precipitation of iron as ferric oxide. Slimeforming bacteria can grow into sufficiently large masses to cause plugging.

The quality of water from surficial and shallow artesian aquifers generally is closer than that of surface water to meeting the standards required for public supply and tends to remain more uniform with time. Surface water may contain suspended solids or organic matter, and to prevent plugging of the aquifer, it may require filtration prior to injection. Surface-water sources tend to be more susceptible to unpredictable or periodic contamination by pollutants in runoff or from point sources, or by the growth of biological organisms. Shallow ground water can be contaminated from point sources or by upconing or lateral migration of saline water. Injected water will mix to some degree with the native water, so that withdrawn water will have some of the constituents of the native water. Thus, the native water composition should also be considered.

Water withdrawn for public-supply use following a period of subsurface storage must meet established public health standards. Contaminants present in the injected water or formed by chemical reactions or biological activity during its residence in the aquifer may render it unfit for consumption. One criteria is that the water should not contain more than $250 \mathrm{mg} / \mathrm{L}$ of chloride (U.S. Environmental Protection Agency, 1977). After a period of withdrawal in which the chloride concentration remains similar to that of the injected water, the chloride concentration will increase gradually until it is similar to that of the native water. It is possible that some of the water of intermediate salinity higher than the potability limit can be combined with water of low salinity so that the mixture meets public-supply standards. If the desired use is other than for public supply (irrigation), the salinity criteria for the mixture may be less stringent. 


\section{Conveyance to Location of Use}

For best results at lowest cost, water for subsurface storage should be obtained and stored near the location of its planned use. For example, it may be obtained in the proximity of water-treatment facilities (from well fields or nearby. canals) for injection in the immediate vicinity. The alternative, which may be made necessary by the remote location of available water or by unsuitable local geologic conditions, is to obtain water from a remote source and to convey it to the location of its use (the waterplant) before or after the process of injection and storage. This means that sources of surplus freshwater need to be near conveyance systems extending to the location of planned use.

There are drawbacks to the long distance conveyance of water. The most common conveyance systems in south Florida are open canals, where water is lost by evaporation or seepage to the water table and might be subject to various forms of contamination. A pipeline would be a better way to convey good quality water, but pipelines for the long distance conveyance of water are uncommon because of their cost.

Construction of pipelines or canals is costly, so existing canals are the conveyance systems most likely to be used. For the very reasons for their construction, most canals in south Florida extend from locations where water is available to where it is needed, and could be used to convey surplus for injection or recovered water. For example, water from Lake Okeechobee or the conservation areas is conveyed to many water-deficient locations along the east and west coasts. Water can be diverted from the Everglades National Park and conveyed to the east coast by the Tamiami Canal. A complex pattern of water diversion and routing from various sources and through various canals might be required to augment freshwater supply in some desired location before or after its injection. Such plans would be tailored for specific problems and needs.

\section{PART III--REGIONAL APPRAISAL OF GEOLOGIC SUITABILITY FOR INJECTION}

The most favorable conditions for storage of freshwater in aquifers containing nonpotable (saline) water occur in formations that are relatively extensive and shallow, are well confined above and below, and in which the natural rate of flow is low. Such formations should be sufficiently permeable to allow safe and costefficient injection and recovery of the desired quantities of freshwater, but not permeable enough to permit buoyancy to be caused by the density contrast between the injected freshwater and the native saline water. The chemical composition of the native water should be such as to minimize chemical reaction with the injected water. 
Most of southern Florida is suitable for implementing the subsurface storage concept, because several confined (artesian) zones composed chiefly of permeable limestone containing brackish water (table 3) underlie the region (F. W. Meyer, written commun., 1981). However, detailed information about these deeper zones has not previously been needed and is, therefore, somewhat limited. This is because most potable water is obtained from shallow unconfined aquifers, such as the Biscayne aquifer of Dade and Broward Counties or from surface storage, and the deeper artesian waters are usually too saline for most purposes.

The approximate depths and thicknesses of six relatively sha1low artesian zones in southern Florida identified on the bas is of currently available data are shown in figure 4. The lower four (Zones I, II, III, and IV) seem to have potential for freshwater storage, though geologic conditions must be investigated locally. The top of Zone I (fig. 5), occurring in Eocene rocks, has been mapped in south Florida by F. W. Meyer and others (written commun., 1981); the remaining zones, however, have not.

A brief description of the six zones is the subject of the remainder of the section and concerns the areal extent, degree of confinement, and hydraulic properties of the zones, together with the quality of the native water. Also included is a brief summary of experimental freshwater injection operations which have been performed in each zone.

\section{Avon Park and Ocala Limestones}

In south Florida, the upper part of the Avon Park Limestone and the Ocala Limestone, both of Eocene age and together identified as Zone I, contain layers of high permeability which might be suitable for injection. In central Florida and in the northern part of the study area, overlying rocks of 01 igocene and Miocene age might also be considered part of the same zone because intervening confining beds pinch out northward over structurally higher rocks in north-central Florida. This condition might also occur locally along the southeastern coast, where confining beds separating the Eocene rocks and Zone II in the overlying 01 igocene rocks are either thin or absent.

The top of Zone I ranges in depth from less than 600 feet below sea level in northern Glades and Martin Counties to more than 1,400 feet in western Lee and Collier Counties (fig. 4). Along the southeastern coast, it ranges from 900 to 1,200 feet below sea level. Its exact depth at a specific location would have to be determined by test drilling because the surface is erosional and, therefore, highly irregular. The effect of erosion is particularly noticeable in Palm Beach, Broward, Dade, and Monroe Counties, where the Ocala Limestone is absent and the Avon Park Limestone represents the top of the zone. 


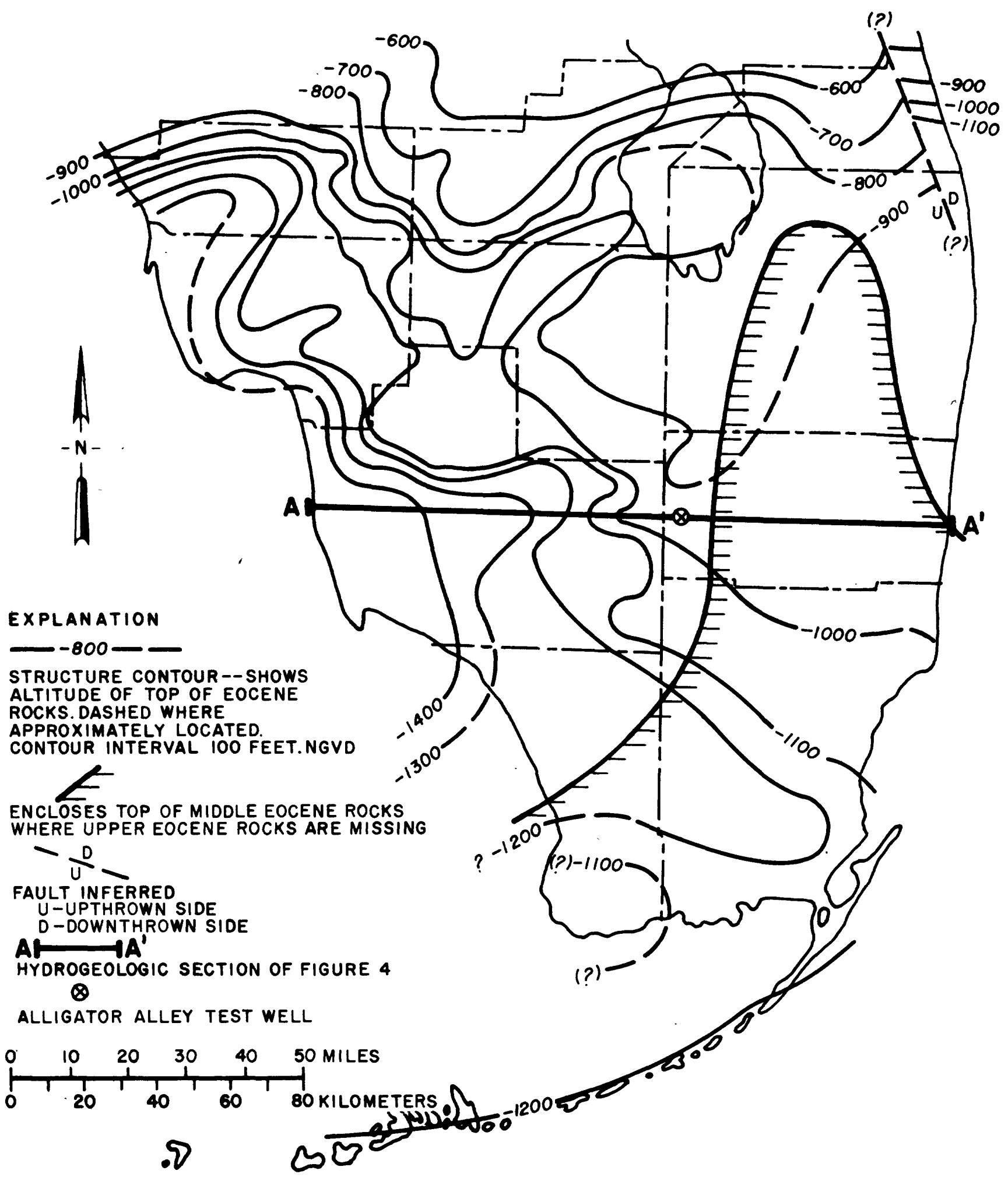

Figure 5.--The top of and upper and middle Eocene rocks (Zone I) in south Florida. Modified from unpublished structural map of Charlotte, Glades, Lee, Hendry, and Collier Counties by John B. Vercellino, Jr., Humble 0i1 and Refining Company, June 1960; Lichtler, W. F. (1960); and Chen, C. (1965). 


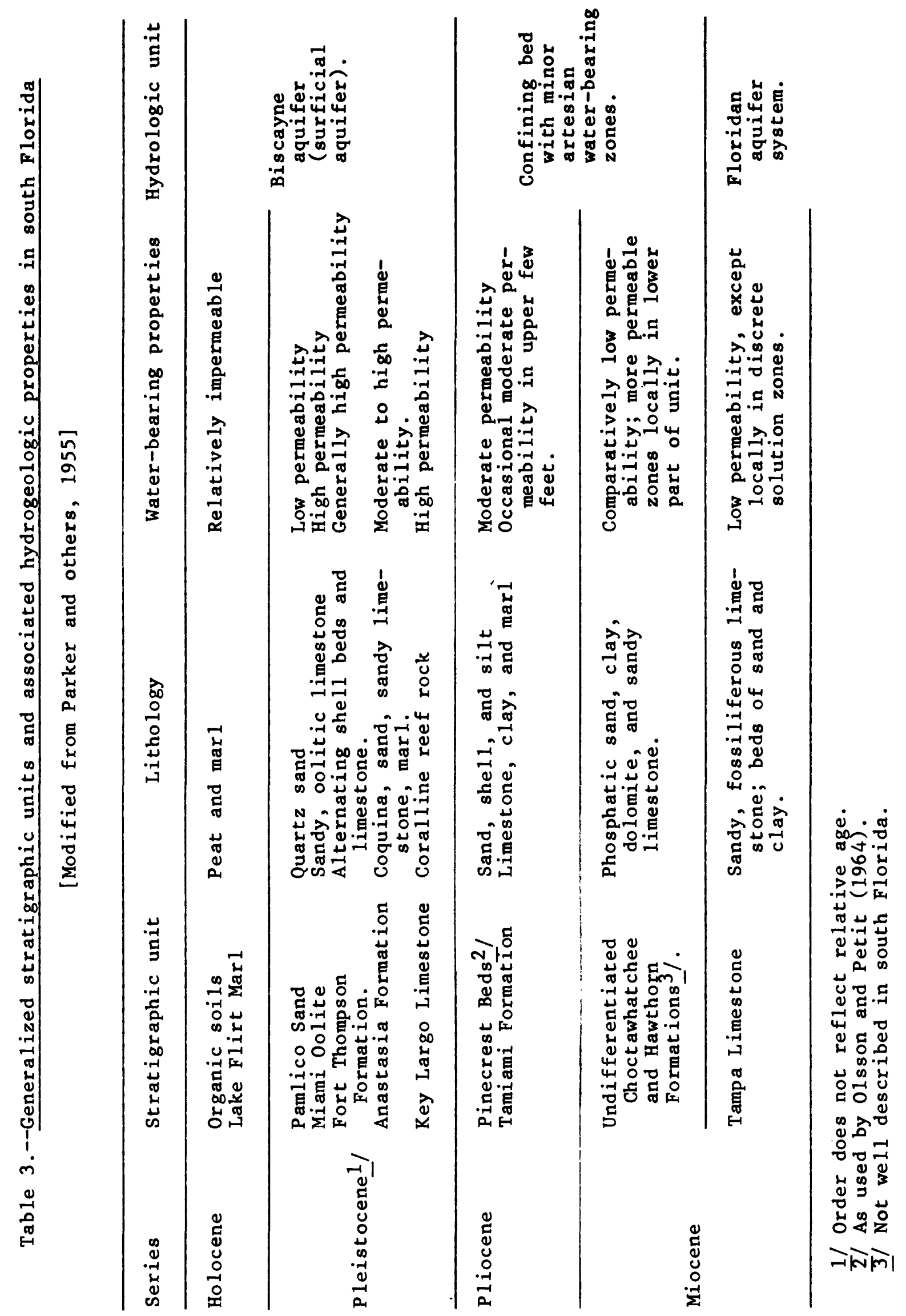




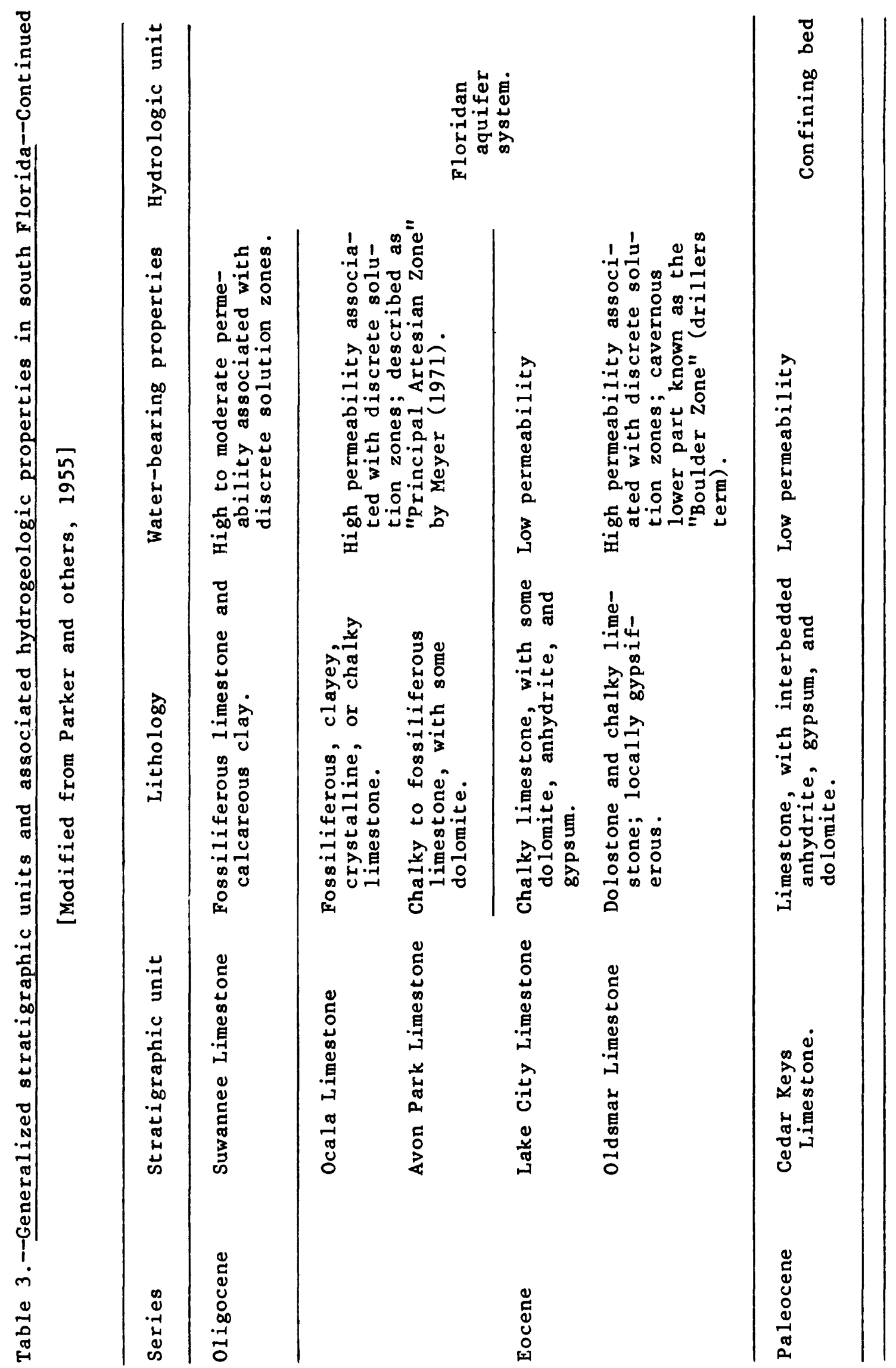


Beds of clay or fine-grained argillaceous limestone (calcilutite) in the overlying lower part of the Suwannee Limestone confine ground water within Zone I. These beds are as much as 50 feet thick at some locations along the east coast and about 400 feet thick on the west coast.

Wells that tap the Eocene rocks usually have higher hydraulic heads than wells open to overlying permeable zones. The native water locally shows wide ranges in salinity associated with discrete intervals. The general trend is an increase with depth until seawater salinity prevails from about 1,400 to 1,800 feet. Waterquality data from a few widely distributed wells suggest that the chloride concentration of the native water in the upper part of the zone ranges from 1,000 to $2,000 \mathrm{mg} / \mathrm{L}$ throughout south Florida, except along the coast where seawater has intruded. Wells that tap the upper 200 to 300 feet usually are highly productive, suggesting high permeability (hydraulic conductivity). The high permeability is usually associated with discrete solution zones in the limestone. Few artesian wells on the west coast tap Zone I because of its greater depth there.

Because of the widespread occurrence and the thickness of Eocene rocks, the upper part of these strata would likely receive consideration in plans for injection and temporary storage of excess freshwater on a sufficiently large scale to require a highly transmissive aquifer. The feasibility of storing excess freshwater in Zone $I$ has been tested at three locations (sites 5, 1 and 2 in fig. 1).

The first injection and recovery tests (table 4) were performed in the Cocoa well field (site 5, fig. 1) in Orange County in eastcentral Florida (Tibbals and Frazee, 1976). Injection was into a 205-foot interval of the Floridan aquifer beneath a confining layer of clay or clayey sand which might be part of the Hawthorn Formation. At this location, the injection zone would likely be within the Avon Park Limestone (Lichtler and others, 1968), although an upper part could be within the Ocala limestone if it is present 10cally. The main receiving zone was believed to be a 5-foot cavity near the bottom of the well (C. H. Tibbals, oral commun., 1983). Five injection periods were each followed almost immediately by recovery. Although water was pumped into the receiving zone from a supply wel1 tapping a secondary artesian aquifer above or in the upper part of the Hawthorn Formation, it would have naturally flowed into the receiving zone (gravity drainage) because of its lower hydraulic head. Recovered water was delivered to the collection system of the well field.

The success of the tests is attributable to the low salinity $(650 \mathrm{mg} / \mathrm{L})$ of the receiving zone, which did not permit buoyancy stratification and which mitigated the deleterious effect of dispersive mixing. As the injection volume was nearly the same in the first three tests and recovery was stopped when the chloride concentration of the recovered water reached $250 \mathrm{mg} / \mathrm{L}$, these tests i1lustrated that recovery efficiency tends to improve appreciably in successive similar cycles. The 75 percent recovery efficiency of the last cycle was the highest observed in such tests in Florida to date (1983). 
Table 4.--Results of U.S. Geological Survey injection and recovery tests at site 5 in Orange County, 1969-70

[From Tibbals and Frazee, 1976]

\begin{tabular}{|c|c|c|c|c|c|}
\hline Cycle & 1 & 2 & 3 & 4 & 5 \\
\hline Quantity injected $\left(\mathrm{gal} \times 10^{6}\right)$ & 11.2 & 11.0 & 11.6 & 33.0 & 28.5 \\
\hline Storage period & $1 /$ & $1 /$ & $1 /$ & 1/ & $1 /$ \\
\hline $\begin{array}{l}\text { Quantity of potable water recovered } 2 \text { / } \\
\quad\left(\text { gal } \times 10^{6}\right)\end{array}$ & 3.8 & 5.7 & 7.7 & 14.4 & 21.4 \\
\hline Percent of recovery & 33.9 & 51.8 & 66.4 & 43.5 & 75.1 \\
\hline Injection rate (gal/min) & 700 & 700 & 675 & 740 & 665 \\
\hline Withdrawal rate (gal/min) & 915 & 955 & 985 & 970 & 970 \\
\hline
\end{tabular}

Transmissivity $-210,000 \mathrm{ft} / \mathrm{d}$ to $750,000 \mathrm{ft} / \mathrm{d}$.

Storage coefficient -0.00007 to 0.0009 .

Injected water chloride concentration - $20 \mathrm{mg} / \mathrm{L}$.

Resident water chloride concentration - $650 \mathrm{mg} / \mathrm{L}$.

Other data: Open hole 285 feet to 490 feet in Avon Park Limestone (possibly Ocala Limestone at top).

Main receiving zone was believed to be a 5-foot cavity near the bottom of the well.

Water source: Supply well tapping a secondary artesian aquifer above or in the upper part of the Hawthorn Formation.

1/ Exact time period not recorded, but recovery began within a few hours of the end of injection.

2/ Recovery (by pumping) was terminated when the chloride concentration of the recovered water reached $250 \mathrm{mg} / \mathrm{L}$. 
Tests (table 5) at site 1 (fig. 1) in Pinellas County in westcentral Florida (Black, Crow, and Eidsness, Inc., 1974) were performed in a well open to a highly permeable and highly saline $(19,700 \mathrm{mg} / \mathrm{L}$ of chloride) part of the Avon Park Limestone. The total uncased zone was 254 feet thick, of which a 40-foot interval was the main receiving zone. Six short injection tests were followed almost immediately by recovery by natural artesian flow.

Fair recoveries ( 43 to 46 percent) were obtained in the first 2 tests, in which recovery immediately followed the end of the injection phase, and also ( 39 percent) in the third test, in which a 10-hour storage period separated the injection and recovery phases. However, less than 1 percent was recovered after the fifth and sixth cycles, which included storage periods of at least 16 hours. The poor results of the last three tests suggested the following possibilities: (1) injected freshwater rapidly migrated upward due to buoyancy, allowing saline water to enter the lower part of the open-hole section of the well (and also suggesting ineffective confining strata above the open-hole section of the wellbore); (2) freshwater outflow was rapidly transmitted through narrow solution channels which were quickly infiltrated by saline water when injection ceased; or (3) mixing of the waters occurred very rapidly due to high hydrodynamic dispersion.

Results (table 6) of the tests of 1975-76 at Jupiter (site 2, fig. 1) in Palm Beach County in southeastern Florida conducted by the Florida Department of Natural Resources (J. J. Plappert, written commun., 1977) were more encouraging, perhaps because the much lower salinity of the native water $(2,000 \mathrm{mg} / \mathrm{L}$ of chloride) did not permit an appreciable degree of buoyancy stratification to occur. The injection well was constructed with 12-inch diameter casing to a depth of 990 feet, and a nominal 12-inch hole was drilled in permeable Eocene limestone to 1,280 feet. Recovery was by natural artesian flow.

The recovery efficiency was zero in the first cycle, but increased with successive cycles until 35 percent efficiency was reported in the fourth cycle. Parameters of the tests and their results were consistent with theoretical analyses (Merritt, 1983) showing that recovery efficiency increases with greater volumes and also with successive cycles.

\section{Suwannee Limestone}

A permeable zone (Zone II), tentatively identified as part of the Suwannee Limestone of oligocene age, might be useful as a receiving zone for injected freshwater. Though unmapped, the zone seems to be areally extensive and about 100 feet thick in south Florida, based upon data from a few widely distributed wells (fig. 4). Its permeability is usually associated with discrete solution zones in the limestone. Zone II is separated from the overlying 


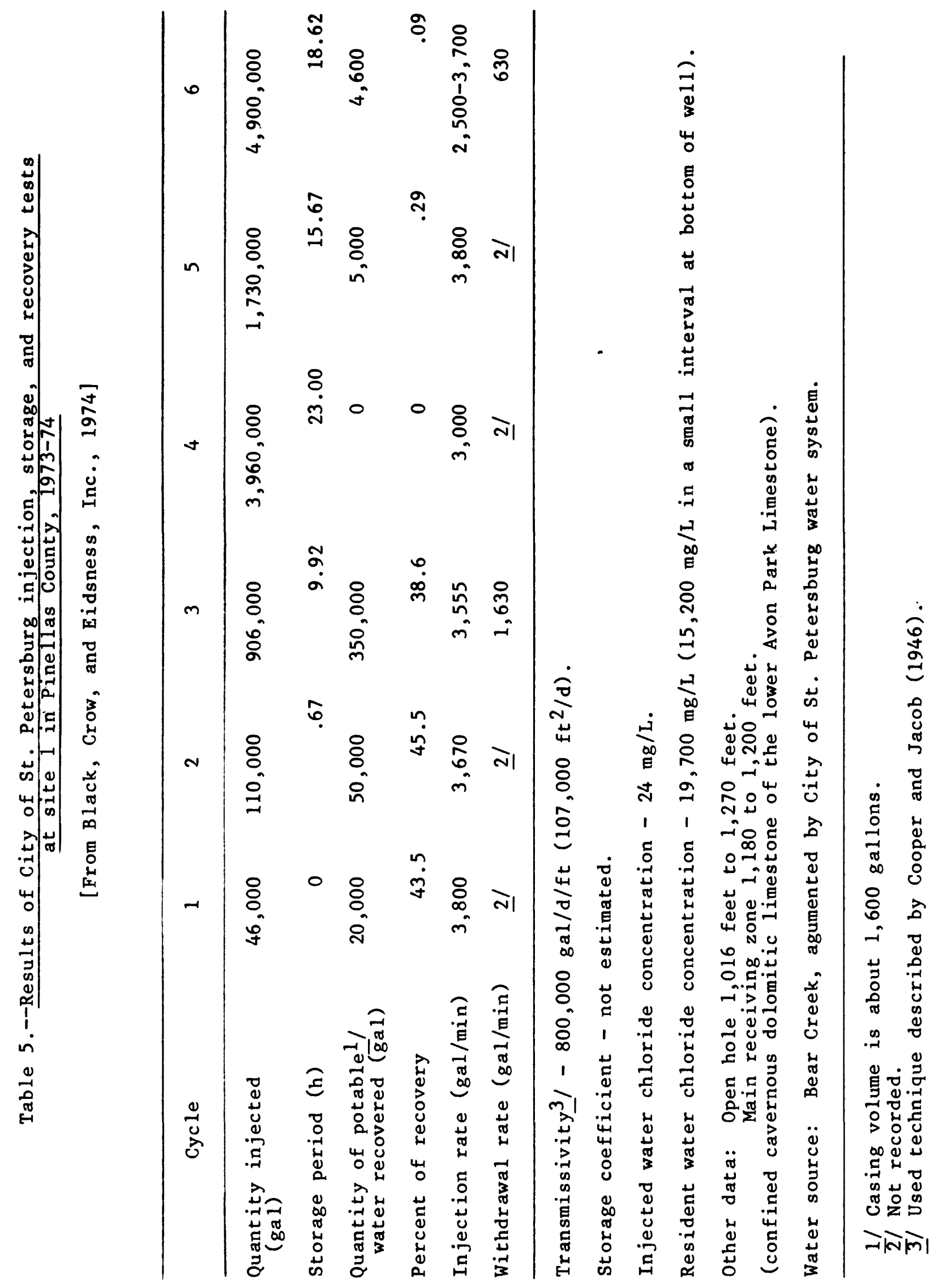


Table 6.--Results of Florida Department of Natural Resources and Florida Department of Environmental Regulation injection, storage, and recovery tests at site 2 in northeast Palm Beach County, 1975-76

[From J. J. Plappert, written commun., 1977]

\begin{tabular}{lcccc}
\hline Cycle & 1 & 2 & 3 & 4 \\
\hline $\begin{array}{l}\text { Quantity injected (Mgal) } \\
\text { Storage period (days) }\end{array}$ & 20.5 & 100 & 306 & 102 \\
$\begin{array}{l}\text { Quantity of potable water recovered1/ } \\
\text { (Mga1) }\end{array}$ & 15 & 30 & 30 & 120 \\
$\begin{array}{l}\text { Percent of recovery } \\
\begin{array}{l}\text { Injection rate (gal/min) } \\
\text { Withdrawal rate (gal/min) }\end{array}\end{array}$ & 0 & 4.7 & 55.5 & 36.1 \\
\hline
\end{tabular}

Transmissivity and storage coefficient - unknown.

Injected water chloride concentration $-65 \mathrm{mg} / \mathrm{L}$.

Resident water chloride concentration $-1,980 \mathrm{mg} / \mathrm{L}$.

Other data: Open hole 990 feet to 1,280 feet (Suwannee and

Avon Park Limestones).

1/ Recovery was terminated when the chloride concentration of the recovered water reached $250 \mathrm{mg} / \mathrm{L}$. 
Zone III and the underlying Zone I by confining beds. The lower confining unit was described as the upper confining unit for Zone I in the preceding section. The overlying confining unit is composed of alternating beds of clay and calcilutite in the lower part of the Tampa Limestone ranging in thickness from about 100 feet on the east coast to about 250 feet on the west coast (fig. 4). Northward into central Florida, both confining units pinch out, and the three zones are hydraulically connected.

Water-quality data from widely distributed wells suggest that the chloride concentration of the native ground water probably ranges between 1,000 and $2,000 \mathrm{mg} / \mathrm{L}$ throughout most of south Florida except near coastal subsea outcrops, where concentrations could approach $20,000 \mathrm{mg} / \mathrm{L}$ due to mixing with seawater. Data from a test well constructed by the U.S. Geological Survey on the north side of Alligator Alley about midway between the east and west coasts (fig. 5) indicate that the chloride concentration in Zone II is about $2,000 \mathrm{mg} / \mathrm{L}$, compared to $1,000 \mathrm{mg} / \mathrm{L}$ in the top of Zone $\mathrm{I}$, and that the hydraulic head in Zone II is about 55 feet above sea level, compared to 58 feet in Zone I. Together with hydraulic head data from Dade County, this suggests the possibility that the hydraulic head in Zone II may be slightly lower than that in Zone I throughout much of south Florida.

Tests to determine the feasibility of storing freshwater in Zone II were conducted by the U.S. Geological Survey in Dade County (site 3, fig. 1) in 1975-78 (F. W. Meyer, oral commun., 1980). The injection well was constructed with $14-$ inch diameter casing to a depth of 955 feet, and a nominal 12-inch hole was drilled to 1,105 feet. The geologic units penetrated by the uncased well bore are the lower part of the Tampa confining bed (955 to 988 feet), Zone II (988 to 1,033 feet), the Suwannee Limestone confining bed $(1,033$ to 1,044 feet) and the Avon Park Limestone (1,044 to 1,105 feet). The upper part of the Avon Park is locally a fine-grained limestone that yielded little or no water to the well.

Results of three injection, storage, and recovery tests (table 7) indicate that significant amounts of freshwater could be recovered successfully after months of residence in the aquifer. A 38 percent recovery efficiency was realized after 6 months of storage. This was less than the 48 percent recovered after nearly 2 months of storage in the previous cycle. However, the three injection and recovery cycles were not designed to test the improvement of recovery efficiency with successive cycles that theoretical studies indicate would occur, and the possible influence of the natural flow system is unknown. 
Table 7.--Results of U.S. Geological Survey injection, storage, and recovery tests at site 3 in Dade County, 1975-80

[F. W. Meyer, oral commun., 1980]

Cycle

Quantity injected (gal $\left.\times 10^{6}\right)$

Storage period (days)

Quantity of potable water recovered $\left(\mathrm{ga} 1 \times 10^{6}\right)$

Percent of recovery

Injection rate (gal/min)

Withdrawa 1 rate (gal/min) 2 /
1

2

3

41.9

$85.0 \quad 208.0$

2

54

181

13.8

$40.7 \quad 80.1$

32.9

$47.8 \quad 38.5$

$1 / 440-780 \quad 854$

800

330

494

450

Transmissivity ${ }^{3} /-10,950 \mathrm{ft}^{2} / \mathrm{d}$.

Storage coefficient ${ }^{3} /-8.4 \times 10^{-5}$.

Injected water chloride concentration $-65 \mathrm{mg} / \mathrm{L}$.

Resident water chloride concentration 4 / - 1,200 mg/L.

1/ Progressive decline due to wellbore plugging.

2/ Natural artesian flow.

$\overline{3} /$ Estimated by model simulation of G-3062 pumping test.

4/ Multi-level composite, range 800 to $2,000 \mathrm{mg} / \mathrm{L}$. 


\section{Tampa Limestone}

Limestone and sandstone of the Tampa Limestone of early Miocene age comprise Zone III, a zone of potential interest in freshwater injection plans. Though unmapped, it seems to be areally extensive, as shown by lithologic data from a few widely distributed wells. It is at least 100 feet thick (fig. 4) and is confined above and below by beds of clay and calcilutite. Permeability of the zone is variable but usually is highest in discrete layers associated with the solution of mollusk-rich beds.

Confining beds of clay in the lower part of the Hawthorn Formation overlie Zone III, except in parts of Lee, Charlotte, Glades, and Hendry Counties. These beds are about 50 feet thick in Collier and Broward Counties. Underlying confining beds, described as overlying confining beds for Zone II in the previous section, pinch out over structurally high 0ligocene and Eocene rocks to the north in central Florida.

Zone III is an important source of brackish artesian water for limited agricultural use in southwest Florida, and of potable artesian water in northwest Glades County and northward into westcentral Florida. In southeastern Florida, the zone is probably somewhat less permeable and, therefore, relatively unimportant as a source of brackish artesian water, although information concerning its hydraulic characteristics is lacking. Based upon water-quality data from a few widely distributed wells, the chloride concentration of the native ground water probably ranges from 1,000 to 2,000 $\mathrm{mg} / \mathrm{L}$, except near coastal outcrops.

Water-level data from two locations suggest that in most of south Florida, the hydraulic head in Zone III is higher than that in the overlying Zone IV and lower than that in the underlying Zone II. Data collected during preparation for freshwater storage feasibility tests in Dade County indicate that water levels in Zones II and III were 42 and 20 feet above sea level. In central Collier County, water levels in Zones III and IV were 52 and 30 feet above sea level. Information on head and salinity relations is scarce, because most wells usually tap several zones and the resulting water-level and salinity data are composites not representative of a single zone. In southwest Florida, penetration of multiple zones has resulted in the interchange of water between artesian zones of different pressures and the contamination of shallow potable aquifers by upward leakage of saline artesian water. No tests have been performed to determine the feasibility of storing freshwater in Zone III. 
Phosphatic limestone of the lower part of the Hawthorn Formation of middle Miocene age comprises a zone (Zone IV) which has been used for freshwater injection. Though unmapped, data from scattered wells indicate that it probably underlies most of southern Florida. It is an important source of brackish artesian water in southwestern Florida. Information on the hydraulic characteristics in southeastern Florida are lacking, and the possibility exists that instead of the permeable limestones that comprise the aquifer in southwest Florida, clay and calcilutite may chiefly comprise the zone in southeast Florida.

Confining beds of clay or calcilutite overlie and underlie the zone throughout much of the region and prevent the free interchange of water with Zones III and V. The underlying clays become thin in Lee, Charlotte, Glades, and Hendry Counties, where Zones IV and III may be hydraulically connected.

Information concerning the salinity of the native water in Zone IV is chiefly limited to southwest Florida, where the chloride concentration in the native water is generally less than $1,000 \mathrm{mg} / \mathrm{L}$. Although generally exceeding the potability standard, it is sufficiently low for limited agricultural use, and some potable water occurs in northeastern Charlotte and northwestern Glades Counties. In southwestern Collier County, water containing about $500 \mathrm{mg} / \mathrm{L}$ of chloride occurs in Hawthorn limestone at about 400 feet, but it has not been determined whether this is within Zone IV or Zone V. The few, widely separated measurements of hydraulic head in Zone IV indicate that it is lower than that in the underlying Zone III but higher than that in overlying zones.

Tests of the feasibility of storing freshwater in Zone IV were conducted by the U.S. Geological Survey (D. J. Fitzpatrick, written commun., 1982) in northeastern Lee County (site 4, fig. 1). The injection we11 was constructed with 447 feet of 10-inch PVC casing, below which a nominal 9-inch hole was drilled to a depth of 600 feet below land surface in limestone of the Hawthorn Formation. The injection zone was between 520 and 580 feet, and its estimated transmissivity was fairly low $\left(700 \mathrm{ft}^{2} / \mathrm{d}\right)$. Hydraulic head in the zone is 48 feet above sea level compared to 18 feet above sea leve 1 in the overlying Zone $V$. The well yielded $165 \mathrm{ga} 1 / \mathrm{min}$ by natural artesian flow, which increased to $250 \mathrm{gal} / \mathrm{min}$ after acid treatment. The chloride concentration of the water was $550 \mathrm{mg} / \mathrm{L}$.

Results of the first cycle (table 8) were encouraging, a1though the period of injection was brief and only a small quantity of freshwater from the nearby Caloosahatchee River was injected. The chloride concentration of the injectant was about $60 \mathrm{mg} / \mathrm{L}$. A volume of potable water equivalent to 39 percent of that injected was recovered in the first cycle. Injection and recovery rates diminished sharply during the first cycle due to plugging, but rates improved significantly after the well was acidized. The low yield of the well suggests that Zone IV is less permeable than Zones II and $I$. 
Table 8.--Results of U.S. Geological Survey injection, storage, and recovery tests at site 4 in Lee County, 1980-82

[From D. J. Fitzpatrick, written commun., 1982]

Cycle

\begin{tabular}{|c|c|c|c|}
\hline Quantity injected $\left(\mathrm{gal} \times 10^{6}\right)$ & 0.571 & $1 / 6.831$ & $2 / 29.026$ \\
\hline Storage period (days) & 0 & 47 & 99 \\
\hline Quantity of potable water recovered ( $\left.\mathrm{gal} \times 10^{6}\right)$ & .221 & .663 & 8.819 \\
\hline Percent of recovery & 38.7 & $3 / 9.7$ & 30.4 \\
\hline Injection rate (gal/min) & $170-350$ & 300 & 300 \\
\hline Withdrawal rate $(\mathrm{gal} / \mathrm{min})^{4} /$ & $95-110$ & $165-175$ & 150 \\
\hline
\end{tabular}

Transmissivity $-700 \mathrm{ft}^{2} / \mathrm{d}$ to $800 \mathrm{ft}^{2} / \mathrm{d}$.

Storage coefficient - Approximately $1 \times 10^{-4}$.

Injected water chloride concentration:

First test $-60 \mathrm{mg} / \mathrm{L}$.

Second test - $150 \mathrm{mg} / \mathrm{L}$ to $350 \mathrm{mg} / \mathrm{L}^{5 /}$

Third test $-80 \mathrm{mg} / \mathrm{L}$ to $100 \mathrm{mg} / \mathrm{L}$ (finished water), $60 \mathrm{mg} / \mathrm{L}$ (raw water).

Resident water chloride concentration - $550 \mathrm{mg} / \mathrm{L}$.

1/ Estimated after loss of water due to equipment failure.

$\underline{2} / 8.548 \times 10^{6}$ gallons of finished water, followed by $20.873 \times 10^{6}$ gallons of raw river water.

3/ Low due to relatively high chloride concentration of injected water. Purpose of test was to test well after acidification.

4/ Natural artesian flow. Improvement in second test due to acidification of well.

5/ Abnormally high due to record low flows in Caloosahatchee River source; decreased during injection. 
The principal purpose of the second cycle was to determine whether acidification of the well had increased its injection capacity. The observed recovery efficiency was an inconclusive result because the chloride concentration of the injectant, which decreased from 350 to $150 \mathrm{mg} / \mathrm{L}$ during the injection phase, was high relative to the potability 1 imit of $250 \mathrm{mg} / \mathrm{L}$. The third cycle began with the injection of treated water followed by injection of raw water from the Caloosahatchee River. The chloride concentration of the treated water generally ranged from 80 to $100 \mathrm{mg} / \mathrm{L}$, and that of the river was was about $60 \mathrm{mg} / \mathrm{L}$. During injection of the untreated river water, there was a steady increase of wellhead pressure due to plugging, which was not ameliorated by periodic backflushing. Recovery efficiency of the third cycle was about 30 percent.

\section{Hawthorn Formation (Upper Part)}

Phosphatic limestone of the upper part of the Hawthorn Formation comprises a relatively shallow zone (Zone V) which locally has been found to be fairly permeable. It is confined above and below by clay and calcilutite of the Hawthorn Formation. Though unmapped, it seems to be areally extensive and comprises an important source of potable water in Charlotte, western Lee, Glades, and Hendry Counties, although its permeability is generally low. Where used as a source of public supply, hydraulic heads in the zone have been lowered significantly by pumping wells: Thus, the restoration of pressures by injection or by gravity drainage of surplus freshwater into the zone near pumping wells (artificial recharge) would be beneficial at any time of the year, provided that water-quality standards are not compromised.

Scattered data suggest that Zone $V$ may grade eastward into beds of limestone, clay, and calcilutite similar to materials comprising a major part of the confining beds above Zone IV. Insufficient data are available to determine whether there are saline permeable sections of Zone $V$ in areas where it is not used for public supply. If there were, they would be highly suited for subsurface storage of freshwater because of the shallow depth (probably less than 500 feet).

\section{$\underline{\text { Tamiami Formation }}$}

Limestone and sandstone, tentatively identified as the Tamiami Formation of Pliocene age, locally comprise a zone (Zone VI) of some permeability. It is an important source of water in parts of Lee, Charlotte, and Collier Counties. The zone is discontinuous and grades eastward into sands and clays which are considered to be confining beds. Where present, it is unconfined along the west coast and semiconfined in eastern Lee County and much of Collier County. 
Like Zone $V$, artificial recharge might be beneficial in areas where the water of Zone VI is potable and used for public supply, provided that water-quality standards are not compromised. Because of the shallow depth, Zone VI would receive consideration for subsurface storage in areas where it is permeable and saline, but the available information is too scanty to determine whether such areas exist.

\section{PART IV - INSTALLATION AND OPERATION OF INJECTION SYSTEM}

The cost-effectiveness of a cyclic injection system (water delivered per dollar spent) depends partly upon such considerations as the need to collect hydrogeologic data, well construction, and the performance and monitoring of operational tests. The activities involved in each of these steps and their costs vary with hydrogeologic conditions and the amounts of water to be stored. They are also a function of the objectives of a program, which might be strictly operational or might also be to obtain additional data for research into hydrogeologic conditions affecting the process. For these reasons, cost evaluation needs to be done on a site-specific basis.

The following sections describe the data collection, construction, and testing steps required to build and operate a cyclic injection system and suggest various factors that should be considered in estimating its cost. Details of experience gained from recent operational tests are included in the discussion to suggest ways to enhance the value of the results obtained from future tests.

\section{Selection of Injection Sites}

The availability of good quality surplus freshwater in a 10cality where additional water will be needed to augment dry-season supply may suggest a consideration of the subsurface storage alternative. This will require an assessment of the local geologic suitability for injection. Information needed to determine site suitability includes locations, thicknesses, and hydraulic properties of permeable layers and confining beds, the local hydraulic gradient, and the quality of the native water. If existing local geologic data are insufficient, test wells will be required. A knowledge of regional hydrogeology will help identify in advance the depth intervals of greatest potential for storage.

\section{Preliminary Data Collection and Analysis}

Lithologic, geophysical, and hydraulic data are needed to describe the hydraulic and chemical characteristics of a proposed injection zone. Drill cuttings from one or more test wells should be examined to obtain lithologic descriptions of successive depth intervals. Rock cores may be obtained for laboratory analyses, which may include measurements of permeability and porosity. 
Geophysical logging of a test well would probably include temperature and fluid conductivity logs to differentiate flow zones on the basis of water quality, and gamma and electric logs for stratigraphic correlation. If the test well is pumped or allowed to flow at a constant rate, fluid velocity logs with supplementary caliper log data can provide information about the relative permeability of various flow zones. A series of static velocity readings might provide more reliable data than continuous data recorded during movement of the fluid velocity probe, particularly if a device to restrict the borehole opening to a fixed diameter is used. It may be possible to isolate flow zones within the well by using packers so that the transmissivity and water quality of each zone may be determined directly.

If the cost is thought to be justified, useful information may be obtained from other logging techniques, such as neutron, electric self-potential, acoustic velocity, or density (gamma-gamma) logs, which can all be used to estimate porosity. The test well might later be converted to either an observation well for the system or to an injection well.

The transmissivity of the entire injection zone determines the rate at which freshwater can be injected under selected injection pressures. The corresponding energy costs may determine whether an injection and recovery system can be cost-effective. Injectionzone transmissivity can be measured with aquifer tests, which might require additional injection-zone observation wells for water-level measurements. Single-well tests can be performed to obtain estimates of transmissivity, but results are not as accurate as those from aquifer tests. Specific capacity tests might also provide transmissivity estimates, if results can be correlated with nearby aquifer test data. A transmissivity estimate for the entire zone may be used in conjunction with flow-meter data to obtain transmissivity estimates for selected subintervals of the zone. If water levels from a distribution of wells are available, they can be used in conjunction with the estimated hydraulic conductivity of zones of highest permeability to determine the rate of natural aquifer flow, possibly of critical importance in evaluating the feasibility of freshwater storage.

Analyses should be made of the quality of the native water in a potential receiving zone, of the freshwater to be injected, and of the resident fluid of adjacent layers which are to be monitored for possible leakage from the receiving zone. This will permit future problems (plugging, leakage, contamination, buoyancy) related to water quality to be more easily resolved. Water samples should be collected during and after construction of the test wells. Samples from various levels of a potential receiving zone would be useful, particularly if it is possible to seal off levels with temporary packers. If surface water is to be injected, measurements of organic and inorganic carbon, suspended solids, and bacterial and biological species are particularly important as they may facilitate the subsequent identification of one or more of these constituents as a cause of well plugging. 
Tests can be performed to determine potential chemical reactions between injected water and injection-zone water, such as ihose which form precipitates which may cause plugging. Prior to the site investigation, water to be used for injection can be combined with water considered to be similar to that of the injection zone. When the site investigation has progressed to the point of collecting injection-zone water samples, these tests can be repeated.

When hydraulic and water-quality data from test wells become available, mathematical modeling techniques can indicate the potential feasibility of cyclic injection at the site. Estimates of porosity, permeability and its vertical distribution, and resident fluid salinity and its vertical distribution can be entered into a digital model such as the INTERA (INTERCOMP Resource Development and Engineering, Inc., 1976 and INTERA Environmental Consultants, Inc., 1979) for a calculation of recovery efficiency. The analysis can indicate whether buoyancy stratification may occur and can provide an estimate of the minimum wellhead pressure which would be required for injection.

Objectives attainable by modeling are limited at this stage, however, as data describing flow in potential receiving zones (discreteness or uniformity, anisotropy, and hydrodynamic dispersion) are usually unavailable and can be measured only during injection tests. However, given routine hydraulic and water-quality data, modeling can rule out injection feasibility at the site or provide an upper estimate of potential recovery efficiency.

To provide perspective concerning the actual cost of the geologic testing required to establish that suitable conditions exist at a site, a hypothetical case is postulated in which a contractor is hired by a public agency to drill a test hole to 1,200 feet below land surface. Lithology, increasing artesian flow, and conductivity measurements suggest a likely in jection zone between 1,000 and 1,100 feet, with less permeable and more saline strata above and below. After a contractor runs gamma, electric, and caliper logs in the mud-filled hole, the bottom 100 feet are filled with cement to seal off the more saline, less permeable zone. Next, 4-inch PVC casing is inserted to 1,000 feet and cemented in place at the bottom to seal off zones overlying the injection zone. After pumping to clean the wellbore, temperature, conductivity, and velocity logs are obtained from the finished open-hole section of the well, and water samples are obtained to be analyzed for all parameters considered to be potentially relevant. Some type of single-well test is performed to obtain an estimate of the transmissivity of the potential injection zone. In 1983 dollars, the most probable cost of these steps would be between $\$ 15,000$ and $\$ 50,000$. This would not include planning costs, unanticipated or incidental costs, computer modeling, or manpower, administrative, or supervisory costs incurred by the sponsoring agency. It does not include installation of sensors to measure physical and chemical parameters during injection and recovery tests. It should be noted that contractor experience and reliability is an important factor, as poor contractor performance and the consequent loss of time would raise administrative and planning costs of the sponsoring agency. If any of a variety of alternative drilling or logging techniques were used, the cost would also vary. 


\section{Well Design and Construction}

Usually, a well is constructed to serve the dual function of injection and recovery. The borehole is lined with casing to confine the injection and recovery water to the wellbore, prevent the hole from caving in, prevent interchange between or contamination of water-bearing zones, and provide pressure control. Three types of casing strings (casing lengths of uniform diameter) might be used in an injection and recovery well. A surface string is of large diameter and prevents contamination of surficial freshwater zones during and after drilling. Intermediate strings prevent collapse of the wellbore while drilling in soft or unconsolidated materials. A final, innermost casing string conducts fluids between the surface and the injection zone.

The design of the well and the plan of installation (the casing program) are based upon the diameter of the final casing string, which should be optimum for the receiving capacity of the injection zone and expected friction losses in the string. Injection wells in south Florida range from 10 to 24 inches in diameter. However, the large diameter wells ( 16 to 24 inches) are for injection of treated wastewater into deep (about 3,000 feet), saline artesian aquifers of very high injection capacity. Recent experimental freshwater injection wells have ranged in diameter from 10 to 14 inches. The final string of casing is' usually seated in the top of the injection zone or near the bottom of an overlying confining layer.

The composition and thickness of the final casing string depends upon strength requirements and the need for corrosion resistance. Steel is commonly used because of its strength; however, plastic pipe has been used with limited success in wells that are cased to depths of less than 500 feet. The disadvantage of plastic pipe is its lesser ability to withstand distortion by heat and pressure during the cement grouting process, and in the possibility that a small open annulus could develop between the cement and the pipe owing to poor bonding of the cement. A new type of cool, light "foam cement" has recently been developed which might make plastic pipe more practical in deep wells. An alternative to plastic pipe is reinforced plastic pipe, composed of sand, fiberglass, and resin, which has been used successfully in wells to depths of 1,000 feet. However, the entire casing string must be supported during installation to reduce tensive stress.

The disadvantage of steel pipe is its vulnerability to corrosion by saline and hydrogen-sulfide rich artesian-zone waters. Where the steel pipe is in contact with corrosive waters, leaks may occur which would allow loss of freshwater during injection and inflow of saline water during withdrawal. Also, plugging of the injection zone in recent tests may have resulted in part from iron precipitates or scale from corrosion of the inside walls of the steel casing. 
To reduce corrosion, the inside of the steel pipe can be sprayed with plastic. However, the plastic coating is susceptible to damage during drilling and to destruction by heat from welding the pipe joints together. Another way to minimize corrosion involves the installation of plastic pipe inside the final steel casing string after its installation. The outside diameter of the plastic pipe must be sufficiently less than the inside diameter of the final string of steel pipe to allow for its insertion and for passage of cementing fluids or sealing devices (packers). In this case, the design of the well is based upon the size of the plastic pipe liner rather than the size of the final string of steel pipe.

The composition and wall thickness of the surface string and intermediate strings depend chiefly on strength requirements. The annulus between casing strings should not be less than 2.5 inches. Therefore, the diameter of the intermediate string should be at least 5 inches greater than the final string, and the diameter of the surface string at least 5 inches greater than the intermediate string.

Casing programs for freshwater injection and recovery wells in south Florida probably would require only the final and surface strings (fig. 6). However, an intermediate string may have to be used if geologic conditions suggest that collapse of unconsolidated material or reduction in the size of the borehole by expansion of clay might prevent installation of the final casing to the required depth. A typical injection and recovery well might be constructed with plain-end steel casings as follows:

\begin{tabular}{|c|c|c|}
\hline Surface & Intermediate & Final \\
\hline 24 & 18 & $103 / 2$ \\
\hline 26 & 20 & $123 / 4$ \\
\hline 26 & 20 & 14 \\
\hline
\end{tabular}

Monitor wells would be constructed similarly, except that smaller casings would be sufficient. The minimum casing size would be 4 inches, which would accommodate either a $33 / 4$ or 3 7/8-inch drill bit.

The casings are supported by cement whose functions are to: (1) bond the outside wall of the casing to the walls of the borehole; (2) restrict movement of water between zones; (3) protect the casing from external corrosion; (4) plug high pressure or lost circulation zones; and (5) repair leaks. Cement grouting takes place after each casing string is seated. In south Florida, cements with moderate sulfate resistance are commonly used because of the sodium and magnesium sulfate content of artesian-zone waters. Bentonite (ge1) and gilsonite are commonly used cement additives which reduce the weight of the slurry to prevent costly cement losses in highly porous zones (lost circulation zones). 


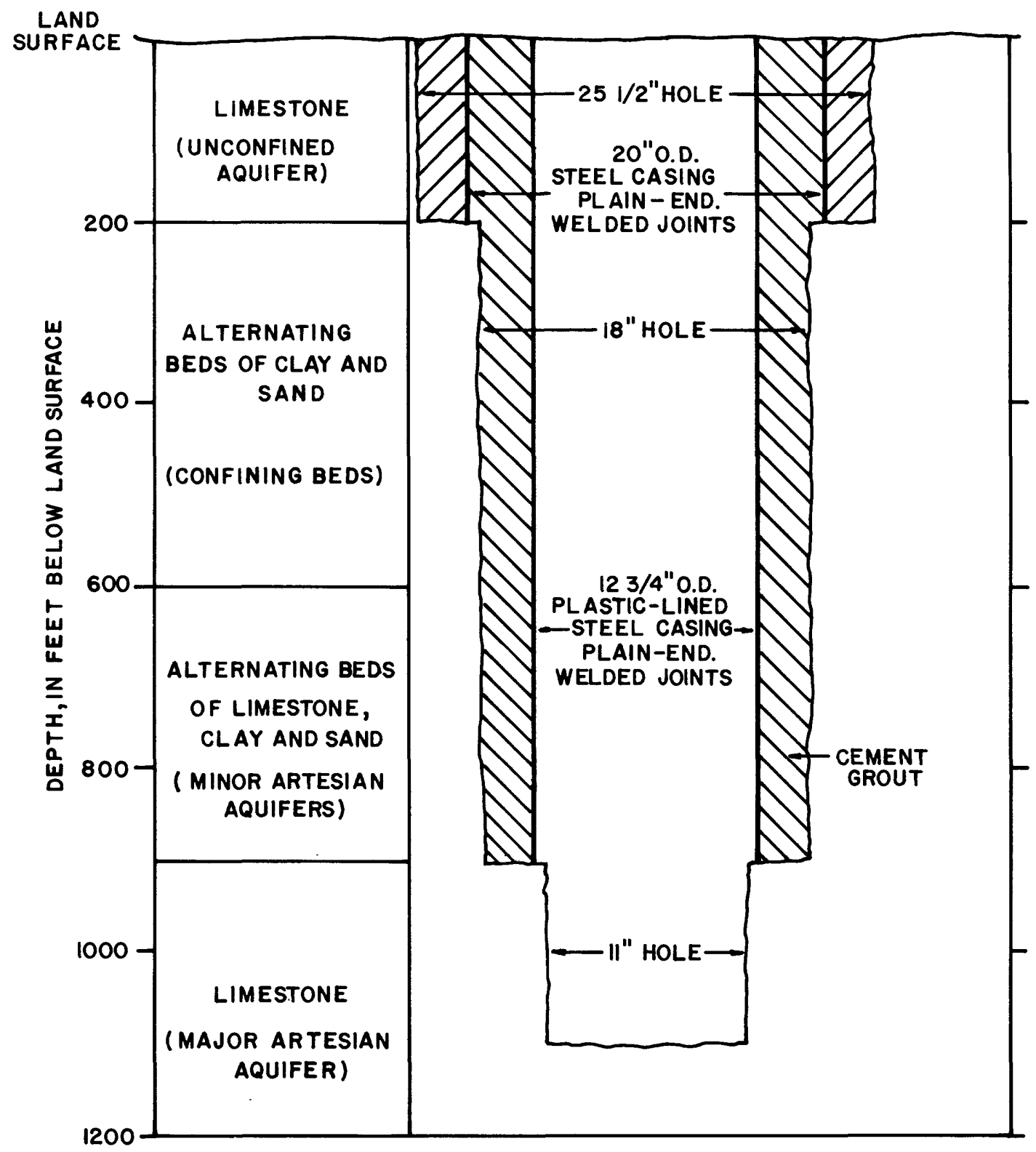

Figure 6.--Construction of a typical freshwater injection and recovery well in south Florida. 
In constructing injection wells, the most common procedure is to drill to the top of the injection zone by the conventional rotary method. The reverse-air method is preferred in the injection zone, however, because the reverse flow of fluids and rock cuttings reduces or eliminates the development of wall cake that could cause formation plugging. An added advantage is the availability of water-quality data in relation to depth.

Certain remedial measures can be taken during well development to minimize plugging. For example, if materials from drilling remaining in the well are a potential cause of plugging, surging and pumping the well upon completion is usually sufficient as a corrective measure. If this procedure is unsuccessful, acidizing the well may solve the problem (Vecchioli and others, 1974). If the injectant contains a high level of suspended solids, pretreatment and filtration may be required. If plugging still occurs during injection, an inexpensive and practical method to restore circulation is by periodically pumping: or backflowing the well to flush the accumulated sediment out of the borehole. Samples of the water and sediment can be collected to determine the cause so that preventive measures can be formulated.

The completed injection well would be equipped with pumping facilities designed to convey freshwater from the source to the well for injection and to convey stored freshwater from the we 11 to the location of its use. Also, periodic backflushing of the well may require conveyance of nonpotable water to a nearby disposal lagoon. Generally, a high-pressure centrifugal pump is installed in part of the pipeline to inject and withdraw from the wel1. Routing of the water is accomplished by placing valves in various sections of the pipeline. This arrangement permits fluid movement through the same pump and flowmeter whichever way the water is routed.

The various items that must be considered in planning the construction of an injection and recovery we11, and which enter into its total cost, are usually specified in the drilling contract. These include the drilling method, drilling sequence, specifications for all materials, requirements for verticality surveys, pressure tests for detecting casing leaks, pump testing, geophysical logging, requirements for offsite disposal of drilling fluids and rock cuttings, response requirements for accidental discharge of pollutants, equipment to control flow at wellhead (blowout preventer), a wellhead assembly, and any requirements for site restoration.

To continue development of the hypothetical example of the previous section for perspective on costs, it is postulated that a decision is reached to inject freshwater into the zone between 1,000 and 1,100 feet. A well similar to the one illustrated in figure 6 is constructed. Twenty-inch surface casing extends to 200 feet, 12 3/4-inch steel casing with an inner coating of epoxy 
to 1,000 feet, and 11-inch open-hole extends to 1,100 feet. In 1983 dollars, the cost of such a well would be in the general range of $\$ 50,000$ to $\$ 100,000$, again excluding unanticipated costs and manpower costs of the sponsoring agency. If several injection wells were drilled in the same location at the same time, there would be some reduction in the cost of each. The drilling permit might require that a contractor be hired to perform a 48- to 72hour aquifer test, using the finished test hole as an observation well, and to analyze the data. The cost of the aquifer test and analysis would probably range from $\$ 10,000$ to $\$ 20,000$.

To use the well for the performance of injection and recovery tests, and for subsequent freshwater storage on an operational basis, a pump, various hardware for controlling flow from the source to the pump, and electrical supplies to provide power to the system are purchased. The Lee County tests (D. J. Fitzpatrick, written commun., 1982) required the purchase of a 40-horsepower centrifugal pump, rated at $500 \mathrm{gal} / \mathrm{min}$ at 210 feet of pressure head (wellhead pressure plus the vertical distance the source water must be lifted). At current (1983) price levels, purchase of this pump and the necessary hardware and electrical supplies would cost between $\$ 5,000$ and $\$ 6,000$. The example pump would probably require about $30 \mathrm{kw}$ of electricity per hour of use, or 22,320 kw in 31 days of continuous, 24-hour use. At current (1983) commercial electric rates, the cost of 1 month of continuous operation would be approximately $\$ 2,000$. No estimate is made here of costs for pretreatment, filtration, or post-treatment of water, or of instrumentation and manpower required during the performance of injection and recovery tests.

\section{Injection and Withdrawal Tests}

Injection and withdrawal tests are essential for the verification of feasibility, because recovery efficiency is affected by properties of the injection zone which are difficult to measure independently. The objectives of operational tests in the near future likely will be partly research oriented because of the technical novelty of cyclic injection and the lack of knowledge about the nature of flow in limestone injection zones. Data control for tests is at the injection and withdrawal well and at one or more observation wells. The number of observation wells is determined by the informational objectives of the test.

If tests are conducted in the absence of observation wells, data collected from the injection well are used for evaluation. Analyses of the increasing salinity of recovered water are used to determine recovery efficiency, the principal measure of the success of the operation. Wellihead pressure and inflow measurements can indicate the degree of plugging. The disadvantage of not having data from observation wells is that important information which could explain the success or failure of the test may be lacking. Subsequent injection tests at other locations may take place without any better prior understanding of the phenomena controlling success or failure. 
The most productive approach to injection and withdrawal testing is the one which maximizes the gain in information, economic factors permitting. It would be advantageous to insta11 as many observation wells as possible, distributed radially so that the injection well is surrounded as completely as possible. In the limestone receiving zones of south Florida, this would help to determine if flow of injected water is anisotropic or along discrete solution channels, factors possibly affecting recoverability. Water-quality data from a sufficient distribution of nearby observation wells may determine the actual position of the injected fluid if there is a preferred direction of movement, and pressure data may indicate anisotropic permeability. Time series of water-quality data from observation wells showing the breakthrough of freshwater can be used to estimate the degree of hydrodynamic dispersion, the major process restricting recoverability. The closer observation wells are to the injection wel1, the less volume of freshwater need be injected to obtain water-quality data describing the arrival of injected water during an injection test, and operational costs are thereby reduced. Distant wells are needed, however, if useful water-level data are to be obtained from aquifer tests.

If overlying or underlying permeable zones separated from the injection zone by confining layers contain potable water, it may be advisable to construct observation wells open to the part of those zones nearest to the receiving layer. Pressure data and waterquality analyses from these wells may serve to detect leakage from the injection zone.

In some cases, a preliminary test injection without data collection has been made to check out equipment. However, this procedure may have drawbacks, in that the chemical data obtained from the closest observation wells for detecting the arrival of the injected water may be unique to the first injection operation. These data are important for determining dispersivity coefficients, detecting flow anisotropies, and differentiating flow zones. During a second injection cycle, the interface between resident water and freshwater may have been altered by the previous injection unless the preceding withdrawal phase was sufficiently long to evacuate all injected water.

Data collection at the injection well during the injection phase would usually include monitoring the rate of inflow and the wellhead pressure. Wellbore plugging is indicated by a decline in the rate accompanied by an increase in pressure. Occasional velocity logger traverses in the injection well may be useful in detecting changes in the permeability distribution. If done before and after backsurging to restore circulation reduced by wellbore plugging, this can show changes caused by plugging. The frequency of sampling of the injected water depends upon the consistency of its chemical composition. Surface water would be checked more frequently than ground water because it tends to exhibit more variability. Values of dissolved oxygen, $\mathrm{pH}$, temperature, and specific 
conductance can be continuously recorded, while periodic complete analysis (including major ions, suspended matter, and bacteriological parameters) can provide information about plugging or chemical reactions affecting the injected water. Some chemical and bacteriological parameters were found useful for evaluation in the Fort Myers freshwater injection tests (D. J. Fitzpatrick, written commun., 1982), and with reference to artificial recharge by Godsy and Ehrlich (1978).

Data collection at the observation wells during the injection phase would include recording water levels and monitoring water quality to determine translatory effects. The least costly and least descriptive water-quality data are multizone composite samples collected by flowing or pumping the well. A more productive method is to install sampling tubes to selected depths corresponding to zones of contrasting hydraulic or chemical characteristics, and collecting samples either manually or with automatic equipment. This may provide accurate data if these zones can be isolated from one another, possibly by the installation of packers. If zones are not isolated, water from various levels of the well migrate to the level from which a sample is being pumped, and a semicomposite sample results which can be difficult to evaluate. This effect was evident in the data from the injection tests (1975-78) at site 3 (fig. 1) in Dade County, even though the zones were partially isolated by the bulk of the sampling tubes.

Making periodic traverses in an observation well with a fluid conductivity probe is another technique for detecting the arrival of injected freshwater in distinct flow zones within the well and for estimating dispersivity parameters in the various zones. In the Lee County (site 4, fig. 1) injection tests (1980-81), the frequency of logging was limited so as to minimize vertical mixing between flow zones caused by the motion of the traversing probe within the wel1. A thin zone of rapid flow of freshwater was clearly defined (D. J. Fitzpatrick, oral commun., 1981). A composite water sample from the open hole part of the well showed a much smaller conductivity decrease.

During the withdrawal phase, water-level or pressure data are usually obtained from observation wells, and comparison with data collected during the injection phase can reveal the occurrence of directionally biased plugging during injection. The quality of the recovered water, a multizone composite, is the key to the success of the operation. Continuous monitoring of specific conductance, $\mathrm{pH}$, temperature, and dissolved oxygen content, together with periodic sampling for complete analysis, may yield information about wellbore plugging or chemical changes in the recovered water. In particular, the first slug of withdrawn water may contain concentrations of suspended matter or bacteriological cultures, which could reveal the source of plugging. 
Several identical injection and withdrawal cycles should be performed, as recovery efficiency improves with successive repetitions due to the accretion of freshwater in the aquifer. The efficiency of the last injection and withdrawal cycle is the best indicator of the potential recovery efficiency of the well. If early tests are performed with short storage periods, and later tests with appreciably longer and varying storage periods, it might be possible to isolate the possible effect of the natural aquifer flow system upon recovery efficiency.

\section{We11-Field Development}

Once the site for a freshwater injection and recovery system has been selected and injection feasibility has been confirmed by analyses of surplus freshwater availability and by test drilling and operation of a pilot injection and recovery system, the next step is to design and construct a well field adequate to offset the projected seasonal freshwater deficits. The basic data needed are the hydraulic characteristics of the injection zone and the water requirements to be served. The hydraulic data determine the maximum injection capacity of a single well which would be feasible from engineering and economic standpoints. Water requirements may vary from a slight augmentation to a complete substitution of water supply for the local water user, which could be a small or large community or an industrial or agricultural concern.

Water requirements should be expressed as a volume rate of withdrawal for the period during which recovered freshwater will be needed. The recovery efficiency observed in tests may be applied to estimate the required volume rate of injection for the period during which freshwater is injected. Injection and withdrawal rates can be compared with the maximum feasible injection and withdrawal capacities of a single well to estimate the number of wells needed. The required number and depth of the wells and the unit cost can then be used for an estimate of the total cost.

The optimum design of the well field depends partly upon whether an appreciable background hydraulic gradient exists. In a saline aquifer, this is usually identified as the regional hydraulic gradient, and whether it needs to be considered depends upon several factors, including the planned length of storage, the thickness and permeability of receiving zones, and the volumes to be injected. Theoretical well-field design methods for localities with uniform background flow have been described by Kimbler and others (1975). Theoretical design methods may be invalid, however, if flow in the aquifer exhibits significant nonuniformity, such as if flow is along discrete solution channels or planes. Flow anisotropy would also require revised designs. 
Some theoretical analyses of recovery efficiency in various we11-field configurations (Merritt, 1983) were based upon an assumption of uniform, isotropic flow in a hypothetical aquifer. Results indicated that a configuration consisting of a ring of peripheral wells surrounding a central well produced recovery efficiencies similar to single-well systems when injection was solely into the central well until freshwater reached the peripheral wells, whereupon injection continued at equal rates into all wells of the configuration. Withdrawal was from all wells at equal rates until the withdrawn water exceeded salinity limits at various wells. This design could be generalized to several concentric rings of wells. Mathematical models such as INTERA "model" (INTERCOMP, 1976; INTERA, 1979) can be implemented to test alternative well-field designs and injection and pumping schedules at specific sites, using techniques similar to those of the theoretical analyses.

\section{PART V - FACTORS AFFECTING FRESHWATER RECOVERABILITY}

An assessment of potable water recoverability should be made before committing resources for operational testing at a chosen site. This requires a qualitative understanding of the relation of recoverability to hydrogeologic parameters characterizing receiving zones and to injection, storage, and recovery regimes. Extensive operational testing in varying environments to determine such relations would be prohibitively expensive. A cost-effective alternative to operational tests is digital modeling, in which many combinations of conditions can be studied with relatively inexpensive computer computations. This approach was used as part of the U.S. Geological Survey technical study of cyclic injection (Merritt, $1982 ; 1983)$.

The INTERA three-dimensional, finite-difference solute and thermal transport model was used to assess the relation of recovery efficiency to hydrogeologic and operational conditions. The analysis consisted of a concept testing approach, as opposed to the more familiar site-specific calibration, verification, and prediction objective of digital modeling. Cyclic injection in a hypothetical aquifer was simulated, incorporating computations for recovery efficiency. Sensitivity analyses were performed to determine how recovery efficiency varies when hydrogeologic or management parameters were varied. As the prototype aquifer of the control was considered representative of injection zones in an area such as south Florida, results showed the effect of variations in conditions that may occur in that area.

The INTERA model incorporated the assumption that flow in the aquifer could be represented as uniform. The effect of smal1-scale flow heterogeneities in creating a transition zone at the interface between the injected and resident fluids is represented in the models by the hydrodynamic dispersion terms. However, large-scale heterogeneities (large solution channels or planes) that do not average out on the scale of the model cannot be represented, and application of model analyses to such injection zones was beyond the scope of the study. The test site at Hialeah in Dade County (site 3, fig. 1) (F. W. Meyer, oral commun., 1980) was used as a prototype for the hypothetical aquifer. Because data from the tests did not determine the degree of dispersive mixing, various dispersion models were used in most analyses. 


\section{Relation to Hydrogeologic Parameters}

Buoyancy stratification refers to the physical process in which injected freshwater rises and flows over the native saline water. This process reduces recovery efficiency because, during recovery, saline water in the lower part of the zone contaminates withdrawn water, while potable water remains in the upper part of the zone.

The permeability of the aquifer material and the density contrast of the injected and native waters determine whether an appreciable level of buoyancy stratification can occur. Generally, low permeability reduces stratification and optimizes recovery efficiency. The permeability and the water quality of the injection zone at the test site at Hialeah in Dade County were such that buoyancy stratification did not occur in simulations of injection, storage, or recovery. When the simulated permeability was increased by a factor of two or three, stratification was still portrayed as negligible by the model. However, when permeability was increased 10 times, computed recovery efficiency was reduced 13.5 percent by stratification. If the resident fluid were more saline, significant buoyancy stratification would have been simulated in lower permeability ranges. In fact, when Hialeah site permeability values were used and the resident fluid was assumed to be seawater, buoyancy stratification caused the computed recovery efficiency to be only about two-thirds of its value when the permeability was one-tenth of the Hialeah values.

Hydrodynamic dispersion is a major factor limiting recovery efficiency. Recovery efficiency decreases significantly as the level of dispersive mixing increases and as more freshwater combines with saline water in a nonpotable mixture.

The more saline the resident fluid, the less volume of water is potable within the transition zone of mixed fresh and saline water that hydrodynamic dispersion causes to develop. Thus, recovery efficiency was shown in model analyses to be less in aquifers of high salinity than in those of moderate salinity. Higher salinity also makes buoyancy stratification more likely to occur for any fixed degree of aquifer permeability decreasing recovery efficiency. Thus, saline aquifers with water just saline enough to be unsuitable for consumptive use are optimum for freshwater injection and recovery, while highly saline aquifers are least promising.

In model analyses in which there was no appreciable vertical dispersion of freshwater into adjacent, less permeable layers still containing native saline water, recovery efficiency was somewhat greater in thin permeable layers than in thick layers. Model computations of recovery efficiency where layer thickness was quadrupled showed a 10.6 percent decrease. 
Background hydraulic gradients can reduce recovery efficiency by conveying the stored freshwater downgradient from the well. In most saline aquifers, the only background hydraulic gradient is the natural regional one. In the hypothetical injection zone considered to represent the Hialeah site, the estimated regional hydraulic gradient of 10 or 20 feet in 45 miles is too small to appreciably move a large volume of injected freshwater during 6 months of storage. If left in storage for 5 years, however, simulations showed that recovery efficiency could be reduced to a fraction of the original value. Substantial potable water would remain in the aquifer unrecoverable by the injection well, though a downgradient wel1 could recover some residual potable water. Genera1ly, the effect of a storage period upon recovery efficiency depends upon permeability, layer thickness, and the volume of freshwater injected. If most injected water were to enter a discrete zone of relatively high permeability, even a modest regional hydraulic gradient might appreciably reduce recovery efficiency after a storage period of several months.

\section{Relation to Design and Management Parameters}

Simulations of an injection and recovery well open only to part of a permeable zone showed recovery efficiency to be virtually the same as when the well was open to the entire zone, although the pattern of flow to and from the well was altered. The rate at which freshwater is injected and recovered apparent ly does not affect recovery efficiency. However, recovery efficiency improved in simulations as the injected volume increased. Exceptions to this rule occurred when there was a small level of interlayer dispersion into adjacent less permeable layers.

Recovery efficiency improves with successive cycles, if each simulated withdrawal phase is stopped when withdrawn water reaches a selected limiting salinity value. In simulations, recovery efficiency improved rapidly in initial cycles, and then more slowly until it was nearly constant after the 12 cycles of the simulation. The 12-cycle efficiency value depended upon the degree of hydrodynamic dispersion, higher efficiencies being reached for lower levels of dispersion.

Recovery efficiency can be reduced if changes occur in the vertical or lateral distribution of permeability due to plugging of the formation around the wellbore during injection. Appreciable amounts of potable water would remain unrecoverable as such in the aquifer when withdrawn water became saline. Model tests were designed with permeability along one axis reduced during the injection phase to 10 percent of its nominal value, and recovery efficiency was reduced to about one-third the value it had in control simulations where this change of anisotropy did not occur. 
Model tests of various multiple well configurations and injection and withdrawal schedules permitted a selection of those producing the best recovery efficiencies. Such configurations consisted of a central well surrounded by perimeter wells. Injection was solely into the central well until freshwater reached the perimeter wells, at which time injection was at equal rates at all wells (sequential injection schedule). Withdrawal was at equal rates at all wells; the perimeter wells were shut down first when withdrawn water became saline, and the central well was shut down later when it also became saline. The number of perimeter wells varied from one to eight in model tests with little effect upon recovery efficiency, which for these arrays and schedules was nearly the same as if injection and withdrawal had been from a single well.

Simultaneous, equal-rate injection and withdrawal in configurations without a central well led to only slightly lower recovery efficiencies, but this schedule in a configuration with a central well led to a recovery efficiency about one-tenth less than that of the sequential injection schedule. When withdrawal only from the central well followed a sequential injection schedule, recovery efficiency was reduced by 6 percent.

\section{PART VI - FURTHER INVESTIGATIVE NEEDS}

There are aspects of subsurface injection and recovery which are poorly described by available data and not well represented by theoretical descriptions. This poses difficulties in making accurate predictions of the recovery efficiency of a proposed system. Examples are: (1) the degree of flow uniformity within the aquifer material; (2) the degree of anisotropy of flow within the aquifer; and (3) the degree of hydrodynamic dispersion (the mixing of injected and native waters by small-scale flow nonuniformities). All three phenomena are highly dependent upon the structure of the aquifer material. Thus, they show the greatest variation in rocks such as limestone that have the greatest variability in structure because of the variety of processes of deposition and alteration by which their hydraulic characteristics are acquired. All permeable zones underlying south Florida considered to have potential for cyclic injection are limestones.

Theoretical assessments of the feasibility of cyclic injection are usually based upon the assumption of approximate flow uniformity. However, there are cavernous zones in south Florida (the "Boulder Zone") in which this assumption would likely be violated. If flow from an injection well is into large discrete conduits or channels, conceptual models usually used for predictions of recovery efficiency do not apply. Whether channels of flow in artesian zones underlying south Florida other than the cavernous Boulder Zone are sufficiently small and well distributed so that flow may be considered uniform is unknown. There are no known conceptual models of the variation of this characteristic among permeable zones and of its relation to depositional and alteration processes. 
Very little is known about the degree of anisotropy in the artesian aquifers of south Florida, although there are indications of anisotropy in some locations (F. W. Meyer, oral commun., 1980). Anisotropy might be the rule rather than the exception. If it prevails locally in some artesian zone, it is unclear whether its orientation would be random or show geometrical regularity related to the direction of natural flow or to processes of deposition and alteration. Whether flow anisotropy and flow nonuniformity are related is unknown. Anistropy is of considerable significance for the planning of injection systems. For example, the design of multiple well systems could be only accomplished given data concerning local flow anisotropies and whether they show geometrical regularities which could be entered into the system design.

Recovery efficiency is directly affected by hydrodynamic dispersion. Not many estimates of the degree of dispersion in aquifers have been made, and none applying to the artesian zones of south Florida. The relation of dispersion to lithology is poorly understood, and its relation to the speed and distance of flow (its scale dependence) is in need of better conceptual development.

Whether it occurs vertically between layers of different permeability has not been established.

If results are obtained from research investigations into these poorly understood processes, they will likely have applicability to practical problems such as cyclic injection. Much could be learned about these processes from operational injection and withdrawal tests performed with surrounding observation wells in sufficient number to define translatory effects with hydraulic and water-quality data.

The assessment of the feasibility of cyclic injection would also benefit from additional operational testing. There is a particular need to perform many successive cycles to determine the full potential of aquifers for freshwater recovery, and to vary the length of storage to test the influence of the natural flow system. The injection test facility at Jupiter in Palm Beach County (site 2, fig. 1) is a promising site for expanded testing and data collection. The existing injection and monitor wells are in a relatively undeveloped area and could be made the nucleus of an expanded system with the construction of other observation wells. Some data are available from the 1977 tests conducted at the site, but data describing hydraulic characteristics and dispersion are lacking. 


\section{SUMMARY}

Deficiencies in potable water supply in certain localities within south Florida occur at times as a result of a combination of two factors: (1) the annual periodicity of natural replenishment of the freshwater system; and (2) problems relating to the timely conveyance of water from where it is available to where it is needed. Freshwater deficiency in the region tends to become manifest either as the virtually complete lack of local natural supply (Monroe County) or as the encroachment of saline water into well fields (east and west coasts). Water deficient areas include localities of large natural supply but even larger water use, such as parts of the east coast.

Where water deficiencies occur, possible remedies may include: (1) improvement of conveyance systems for transfer of water to 1ocations of need; (2) relocation or redistribution of well fields to lessen the possibility of saline-water intrusion; (3) desalination; (4) restriction of water use; (5) reclamation of wastewater; and (6) water-conservation practices. One conservation alternative is cyclic injection, the use of confined aquifers containing nonpotable water as temporary reservoirs for surplus freshwater. Injection and recovery might be done annually with injection of surplus freshwater during the wet season, followed by a short storage period and subsequent withdrawal as needed during the dry season.

Considered as a whole, the fresh surface-water and groundwater system of south Florida likely contains sufficient surplus for the practice. The problem of water availability becomes a matter of resolving the following questions: (1) when is it available; (2) where and from what source will it be obtained; (3) in what quantity can it be obtained; (4) what is its quality; and (5) do efficient means exist to convey it to the location of its future use?

Freshwater might be available in surplus during the wet season from the same ground-water or surface-water sources that might become deficient during the dry season, such as the well fields in the surficial or shallow artesian aquifers of the east or west coasts. It may be available as excess storage in surface reservoirs destined to be discharged into the sea or into Everglades National Park by the canal system. Quantification of the amount of water available requires analyses specific to the source to be used and the location where it is to be obtained.

Water-use data for south Florida in 1977 show that Lake Okeechobee, the water conservation areas, and the Biscayne aquifer of Dade and Broward Counties are the major sources for water used in the 10-county study area, but that the relatively less productive aquifers of the west coast also provide large amounts of water for agriculture and public supply. An analysis of quantities of water discharged at coastal and inland sites quantifies excess surface water at these locations during periods of maximum discharge. If the amount of discharge required to maintain ecosystems can be estimated, these analyses suggest amounts of water that might be available for cyclic injection. 
The chemical composition of water to be injected is an important factor from two standpoints: (1) its effect upon the injection process; and (2) use of the recovered water. Suspended matter in the injected water and precipitates formed by chemical reaction can cause plugging. In addition to quantity and quality requirements, surplus freshwater must be obtained near the location of its use or near an intervening conveyance system for its subsurface storage to be helpful.

Geologic conditions in southern Florida are generally suitable for subsurface storage, because several artesian zones composed chiefly of permeable limestone saturated with brackish water underlie the region. At least four artesian zones have potential for freshwater storage. The one with the greatest potential is identified as the Ocala Limestone and the upper part of the underlying Avon Park Limestone of Eocene age (Zone I). The feasibility of storing excess freshwater in this zone has been tested in orange, Pinellas, and Palm Beach Counties, with results ranging from excellent to poor depending upon hydrogeologic conditions.

Tests to determine the feasibility of storing freshwater within the Suwannee Formation (Zone II) were conducted in Dade County in 1975-78. Three injection, storage, and recovery tests indicated that appreciable amounts of freshwater could be recovered after months of residence in the zone. Tests in the Hawthorn Formation (Zone IV) have been conducted in northeastern Lee County with results which varied from poor to promising depending upon the quality of the injected water.

Information needed to assess the suitability of underground formations at a site chosen for injection of surplus water includes depths and thicknesses of permeable layers and confining beds and the chemistry of native waters. This information can be obtained from lithologic and geophysical logging. Complete analyses should be made of the quality of the receiving zone native water, the injected water, and the native water of adjacent layers to be monitored for possible leakage from the receiving zone. Mathematical modeling techniques may be implemented to provide a preliminary indication of the feasibility of cylic injection at the chosen location.

Verification of cyclic injection feasibility at a site, together with dependable estimates of recovery efficiency, can only be determined by performing actual injection and recovery tests. The design of the well is based on hydrogeologic data that were used in the suitability assessment. From these data, the designer anticipates the lithologic sequence to be penetrated, depth of the well, types of casing and cement, and drilling methods. 
The basic data needed for the design and construction of a cyclic injection well field are the hydraulic characteristics of the injection zone at the site and the water requirements to be satisfied. The hydraulic data are used to determine the maximum injection capacity of a single well that would be feasible from engineering and economic standpoints. Required injection and withdrawal rates can be compared with the single-well capacity to estimate the number of wells needed.

An inherent problem of injection wells is the reduction of capacity by plugging of the formation around the wellbore by suspended solids in the injectant. If the injectant contains a high level of suspended solids, pretreatment and filtration may be required. Recent injection tests indicate that, in some cases, an inexpensive and practical way to restore circulation lost because of plugging is by periodic backflushing.

Digital models were used to theoretically analyze the relation of recovery efficiency to various hydrogeologic conditions that could prevail in brackish aquifers chosen for freshwater storage. Efforts to predict injection feasibility at specific sites and to design operational well fields are hampered because of a lack of specific knowledge concerning the nature of flow in the artesian zones of south Florida. It is important to know if theoretical flow uniformity assumptions are violated or if flow is anisotropic. More information is needed about the degree of hydrodynamic dispersion and its variability in the artesian zones. Much could be learned from injection and withdrawal tests performed with an adequate number of surrounding observation wells, each recording data from hydraulically isolated depth intervals of differing hydraulic characteristics. Repeated cycles of injection and recovery need to be performed to operationally determine the full potential of aquifers for freshwater conservation by cyclic injection.

That freshwater injection and recovery can be done has been demonstrated operationally in south Florida, although the potential recovery efficiency after repeated cycles has not been demonstrated, and questions remain about the displacement effect of the regional flow system. The failure of some operational tests show that success depends upon the presense of favorable hydrogeologic conditions. Plans for the installation of a cyclic injection system should include careful site characterization, operational testing, and a consideration of the costs relative to other water supply or conservation alternatives. 


\section{SELECTED REFERENCES}

Bearden, H. W., 1973, Hydrologic data for 1971, Broward County, Florida: U.S. Geological Survey open-file report FL-73016, 87 p.

- 1974a, Hydrologic data for 1972, Broward County, Florida: U.S. Geological Survey open-file report FL-74005, 97 p.

-- 1974b, Hydrologic data for 1973, Broward County, Florida: U.S. Geological Survey open-file report FL-74028, 64 p.

- 1974c, Ground-water resources of the Hollywood area, Florida: U.S. Geological Survey open-file report FL-74015, 71 p.

- 1975, Hydrologic data for 1974, Broward County, Florida: U.S. Geological Survey open-file report FL-74006, 76 p.

Bishop, E. W., 1956, Geology and ground-water resources of Highlands County, Florida: Florida Geological Survey Report of Investigations no. $15,115 \mathrm{p}$.

Black, Crow, and Eidsness, Inc., 1974, Results of drilling and testing of the stormwater injection well for the City of St. Petersburg, Florida.

1976, Results of drilling and testing Floridan aquifer watersupply wells for the City of Cape Coral, Florida.

Boggess, D. H., 1968, Water-supply problems in southwest Florida: U.S. Geological Survey open-file report FL-68003, 27 p.

1973, The effects of plugging a deep artesian well on the concentration of chloride in water in the water-table aquifer at Highland Estates, Lee County, Florida: U.S. Geological Survey open-file report $73003,20 \mathrm{p}$.

--- 1974, Saline ground-water resources of Lee County, Florida: U.S. Geological Survey open-file report FL-74247, 62 p.

Brown, M. C., and Reece, D. E., 1979, Hydrogeologic reconnaissance of the Floridan aquifer system, Upper East Coast Planning Area: South Florida Water Management District Technical Map Series 79-1, 11 sheets.

Buono, Anthony, and Rutledge, A. T., 1979, Configuration of the top of the Floridan aquifer, Southwest Florida Water Management District and adjacent areas: U.S. Geological Survey Water-Resources Investigations 78-34, 1 sheet.

Chen, Chih Shan, 1965, The regional lithostratigraphic analysis of Paleocene and Eocene rocks of Florida: Florida Geological Survey Bulletin no. 45, 105 p. 
Cohen, Philip, and Durfor, C. N., 1967, Artificial recharge experiments utilizing renovated sewage-plant effluent - a feasibility study at Bay Park, New York, U.S.A.: International Association of Scientific Hydrology Publication 72, p. 194-199.

Cooper, H. H., Jr., and Jacob, C. E., 1946, A generalized graphical method for evaluating formation constants and summarizing well-field history: Transactions of the American Geophysical Union, v. 27 , no. 4, p. 526-534.

Crain, L. J., Hughes, G. H., and Sne11, L. J., 1975, Water resources of Indian River County, Florida: Florida Bureau of Geology Report of Investigations no. 80, 75 p.

Dames and Moore, 1975, Floridan aquifer water-supply investigation, Turkey Point area, Dade County, Florida: Dames and Moore, Boca Raton, Florida.

Fish, J. E., Causaras, Carmen, and O'Donne11, T. H., 1983, Records of selected wells and lithologic logs of test holes, Hendry County and adjacent areas, Florida: U.S. Geological Survey Open-File Report 83-134.

Franks, B. J., editor, 1982, Principal aquifers in Florida: U.S. Geological Survey Open-File Report 82-255, map report, 4 sheets.

Gleason, P. J., 1980, Water, oil, and the geology of Collier, Lee, and Hendry Counties, the 1980 field trip experience: Miami Geological Society, 80 p.

Godsy, E. M., and Ehrlich, G. G., 1978, Reconnaissance for microbial activity in the Magothy aquifer, Bay Park, New York, four years after artificial recharge: Journal of Research of the U.S. Geological Survey, v. 6, no. 6, p. 829-836.

Grantham, R. C., and Sherwood, C. B., 1968, Chemical quality of water of Broward County, Florida: Florida Division of Geology Report of Investigations no. $51,52 \mathrm{p}$.

INTERA Environmental Consultants, Inc., 1979, Revision of the documentation for a model for calculating effects of liquid waste disposal in deep saline aquifers: U.S. Geological Survey Water-Resources Investigations 79-96, $73 \mathrm{p}$.

INTERCOMP Resources Development and Engineering, Inc., 1976, A model for calculating effects of liquid waste disposal in deep saline aquifers, Part 1--development, Part 2--documentation: U.S. Geological Survey Water-Resources Investigations 76-21, $253 \mathrm{p}$.

Johnston, R. H., 1978, Planning report for the southeastern limestone regional aquifer system analysis: U.S. Geological Survey Open-File Report 78-516, 26 p. 
Khanal, N. N., 1980, Advanced water-supply alternatives for the Upper East Coast Planning Area; Part I - feasibility of cyclic storage of freshwater in a brackish aquifer and Part II desalination alternative: South Florida Water Management District Technical Publication no. 80-6, 75 p.

Kimbler, O. K., Kaymann, R. G., and Whitehead, W. R., 1975, Cyclic storage of freshwater in saline aquifers: Louisiana WaterResources Research Institute Bulletin no. $10,78 \mathrm{p}$.

Klein, Howard, 1980, Water-resources investigations, Collier County, Florida: U.S. Geologica1 Survey Open-File Report 80-1207, $29 \mathrm{p}$.

Klein, Howard, Armbruster, J. T., McPherson, B. F., and Freiberger, H. J., 1974, Water and the south Florida environment: U.S. Geological Survey Water-Resources Investigations 24-75, 165 p.

Klein, Howard, Schroeder, M. C., and Lichtler, W. F., 1964, Geology and ground-water resources of Glades and Hendry Counties, Florida: Florida Geological Survey Report of Investigations no. $37,101 \mathrm{p}$.

Konikow, L. F., and Bredehoeft, J. D., 1978, Computer model of twodimensional solute transport and dispersion in ground water: U.S. Geological Survey Techniques of Water-Resources Investigations, Book 7, Chapter C-2, 90 p.

Land, L. F., 1975, Effects of lowering interior canal stages on saltwater intrusion into the shallow aquifer in southeast $P a 1 \mathrm{~m}$ Beach County, Florida: U.S. Geological Survey open-file report FL-75074, 59 p.

1977, Ground-water resources of the Riviera Beach area, Palm Beach County, Florida: U.S. Geological Survey Water-Resources Investigations $77-47,38 \mathrm{p}$.

Land, L. F., Rodis, H. G., and Schneider, J. J., 1973, Appraisal of the water resources of eastern Palm Beach County, Florida: Florida Bureau of Geology Report of Investigations no. 67, $64 \mathrm{p}$.

Leach, S. D., and Healy, H. G., 1979, Estimated water use in Florida, 1977: U.S. Geological Survey Water-Resources Investigations $79-112,76$ p.

Leach, S. D., Klein, Howard, and Hampton, M. L., 1972, Hydrologic effects of water control and management of southeastern Florida: Florida Bureau of Geology Report of Investigations no. $60,115 \mathrm{p}$.

Lichtler, W. F., 1960, Geology and ground-water resources of Martin County, Florida: Florida Geological Survey Report of Investigations no. 23,149 p. 
Lichtler, W. F., Anderson, Warren, and Joyner, B. F., 1968, Water resources of Orange County, Florida: Florida Geological Survey Report of Investigations $50,150 \mathrm{p}$.

MacVicar, T. K., 1981 , Frequency analys is of rainfall maximum for central and south Florida: South Florida Water Management District Technical Publication no. 81-3, 69 p.

Maher, J. C., 1971, Geologic framework and petroleum potential of the At lantic Coastal Plain and Continental Shelf, with a section on stratigraphy: U.S. Geological Survey Professional Paper $659,98 \mathrm{p}$.

McCoy, H. J., 1962, Ground-water resources of Collier County, Florida: Florida Geological Survey Report of Investigations no. $31,82 \mathrm{p}$.

--- 1972, Hydrology of western Collier County, Florida: Florida Bureau of Geology Report of Investigations no. 63, 32 p.

--- 1973a, Effects of the feeder canal on the water resources of the Fort Lauderdale Prospect well-field area: U.S. Geological Survey open-file report FL-73019, 24 p.

-- 1973b, Summary of hydrologic conditions in Collier County, Florida, 1972: U.S. Geological Survey open-file report FL-73022, 118 p.

--- 1974, Summary of hydrologic conditions in Collier County, Florida, 1973: U.S. Geological Survey open-file report FL-74030, 99 p.

-- 1975, Summary of hydrologic conditions in Collier County, Florida, 1974: U.S. Geological Survey open-file report FL-75007, $103 \mathrm{p}$.

Merritt, M. L., 1982, Subsurface storage of freshwater, south Florida: Proceedings of the ASCE National Specialty Conference on environmentally sound water and soil management, Orlando, Florida, p. 242-250.

1983, Subsurface storage of freshwater in south Florida: A digital model analysis of recoverability: U.S. Geological Survey water supply paper (in press) (Interim release as OpenFile Report 83-536, 73 p.)

Meyer, F. W., 1971, Saline artesian water as a supplement: Journal of the American Water Works Association, v. 63, no. 2, p. 65-71.

- 1974, Evaluation of hydraulic characteristics of a deep artesian aquifer from natural water-level fluctuations, Miami, Florida: Florida Bureau of Geology Report of Investigations no. $75,32 \mathrm{p}$. 
Missimer, T. M., and Gardner, R. A., 1976, High resolution seismic reflection profiling for mapping shallow aquifers in Lee County, Florida: U.S. Geological Survey Water-Resources Investigations $76-45,30 \mathrm{p}$.

Missimer, T. M., and O'Donne11, T. H., 1975, Fluctuations of groundwater levels in Lee County, Florida, in 1974: U.S. Geological Survey open-file report FL-75008.

O'Donne11, T. H., 1977, Municipal water supplies in Lee County, Florida, 1974: U.S. Geological Survey Open-File Report 77-277, 96 p.

01sson, A. A., and Petit, R. E., 1964, Some Neogene Mollusca from Florida and the Carolinas: Bulletin of American Paleontology, v. 47, no. 217 , p. 509-574.

Parker, G. G., Ferguson, G. E., Love, S. K., and others, 1955, Water resources of southeastern Florida: U.S. Geological Survey Water-Supply Paper 1255, 965 p.

Puri, H. S., and Winston, G. 0., 1974, Geologic framework of the high transmissivity zones in south Florida: Florida Bureau of Geology Special Publication no. 20, 101 p.

Reece, D. E., Brown, M. P., and Hynes, S. D., 1980, Hydrogeologic data collected from the Upper East Coast Planning Area: South Florida Water Management District Technical Publication no. $80-5,91 \mathrm{p}$.

Schroeder, M. C., Milliken, D. L., and Love, S. K., 1954, Water resources of Palm Beach County, Florida: Florida Geological Survey Report of Investigations no. 13, $63 \mathrm{p}$.

Scott, W. B., Land, L. F., and Rodis, H. G., 1977, Saltwater intrusion in the shallow aquifer in Martin and Palm Beach Counties, Florida: U.S. Geological Survey Water-Resources Investigations $76-135,1$ sheet.

Sherwood, C. B., McCoy, H. J., and Galliher, C. F., 1973, Water resources of Broward County, Florida: Florida Bureau of Geology Report of Investigations no. 65, $141 \mathrm{p}$.

Sinclair, W. C., 1977, Experimental study of artificial recharge alternatives in northwest Hillsborough County, Florida: U.S. Geological Survey Water-Resources Investigations 77-13, 52 p.

South Florida Water Management District, 1978, Water use and supply development plan - executive summary.

---- 1979, Water use and supply development plan - summary status report, lower west coast. 
Sprou1, C. R., Boggess, D. H., and Woodward, H. J., 1972, Salinewater intrusion from deep artesian sources in the McGregor Isles area of Lee County, Florida: Florida Bureau of Geology Information Circular no. 75, 30 p.

Stringfield, V. T., 1936, Artesian water in the Florida peninsula: U.S. Geological Survey Water-Supply Paper 773-C, 195 p.

Sutcliffe, Horace, Jr., 1975, Appraisal of the water resources of Charlotte County, Florida: Florida Bureau of Geology Report of Investigations no. $78,53 \mathrm{p}$.

Swayze, L. J., and McPherson, B. F., 1977, The effects of the Fahka Union Canal system on water levels in the Fahkahatchee Strand, Collier County, Florida: J.S. Geological Survey Water-Resources Investigations $77-61,19 \mathrm{p}$.

Tarver, G. R., 1964, Hydrology of the Biscayne aquifer in the Pompano Beach area, Broward County, Florida: Florida Division of Geology Report of Investigations no. 36, $47 \mathrm{p}$.

Tibbals, C. H., and Frazee, J. M., Jr., 1976, Ground-water hydrology of the Cocoa well-field area, Orange County, Florida: U.S. Geological Survey Open-File Report 75-676, 67 p.

U.S. Army Corps of Engineers, 1980, Golden Gate Estates: Jacksonville District, April 1980, Reconnaissance Report.

U.S. Environmental Protection Agency, 1977, Quality criteria for water, 1976: $256 \mathrm{p}$.

Vecchioli, John, Bennett, G. D., Pearson, F. J., Jr., and Cerrillo, L. A., 1974, Deep-well artificial-recharge experiments at Bay Park, Long Island, New York: Hydraulic effects of recharging the Magothy aquifer, Bay Park, New York, with tertiary-treated sewage: U.S. Geological Survey Professional Paper 751-F, 21 p.

Vecchioli, John, Oliva, J. A., Ragone, S. E., and Ku, H. F. H., 1975, Wastewater reclamation and recharge, Bay Park, New York: American Society of Civil Engineers, Journal of the Environmental Engineering Division, v. 101, no. EE2, Proceedings Paper 11232, p. 201-214.

Vernon, R. 0., 1955, Approximate top of the Floridan aquifer: Florida Engineering and Industrial Experiment station, 1 sheet.

Wedderburn, L. E., and Knapp, M. S., 1983, Field investigation into the feasibility of storing fresh water in saline portions of the Floridan Aquifer System, St. Lucie County, Florida: South Florida Water Management District Technical Publication no. $83-7,71 \mathrm{p}$.

Wilson, W. E., 1977, Ground-water resources of De Soto and Hardee Counties, Florida: Florida Bureau of Geology Report of Investigations no. 83, 102 p. 